\title{
VEGETATION CHARACTERISTICS OF THE MORYŃSKIE HILLS (NW POLAND)
}

\author{
Marcin Kagan, Wojciech SzWed
}

\author{
M. Kagan, Regional Directorate of State Forests in Szczecin, Forest District Chojna, Szczecińska 36, 74-500 \\ Chojna, Poland \\ W. Szwed, Department of Forest Botany, Poznań University of Life Sciences, Wojska Polskiego 71 C, 60-625 \\ Poznań, Poland, e-mail: w-szwed@wp.pl
}

(Received: September 19, 2013. Accepted: November 14, 2013)

\begin{abstract}
The aim of this study was to characterise the flora and plant communities in the Moryńskie Hills, Poland. A total of 45 transects and 23 phytosociological relevés were established. Plant communities were identified based on the description of the test patch of the vegetation cover. The paper presents floristic analyses of vascular plants, which includes the taxonomic affiliation of species, their life forms according to Raunkiaer, and the species share in the geographical and historical groups. The results have been compiled and presented in tables and graphs, with a brief discussion. The non-forest communities occupy the largest area: xerothermic swards, meadows and pastures and to a lesser extent, scrub communities. Forests are represented by a riparian slope elm-ash wood Violo odoratae-Ulmetum minoris.
\end{abstract}

KEY WORDS: Moryńskie Hills, xerothermic grasslands, flora, plant communities

\section{INTRODUCTION}

The areas around the Moryńskie Hills have been utilised by agriculture for centuries. The Hills are a series of morains of the Myślibórz stage of the Würm glaciation with relatively steep slopes and considerable insolation, running from Kostrzynek/Oder through Myślibórz to Barlinek. In the past the vegetation cover was influenced only by natural factors, with all changes occurring in nature being long-term and slow. Since the time when human activity started to seriously affect the environment, the changes in nature have been drastically accelerated. Interest in xerothermic vegetation in Poland has been observed for years. Examples of such research include e.g. a publication by Czeczotowa (1948), SŁAwiŃSKI (1952), Celí́ski (1953 a, b, 1954, 1957), FiJAeKOWsKI (1957), Celiński \& Filipek (1958), Ceynowa (1968), FILIPEK (1974) as well as numerous contemporary studies. The basic practical information concerning xerothermic grasslands, their distribution, environmental requirements, characteristic species, identified plant associations as well as threats and protection measures are presented in "Poradnik Ochrony Siedlisk" [Habitat Protection Guidelines] (PerzA-
NOWSKa \& KuJAWA-PaWlaczyK 2004 and literature cited therein).

The aim of this study was to characterise flora in terms of plant communities in the Moryńskie Hills. Moreover, the study focuses on the identification of threats to flora and vegetation and presents recommendations for natural management of the discussed communities.

\section{THE AREA CHARACTERISTIC}

The study area is located in north-western Poland (Fig. 1) in the Gryfino county, in the Moryńskie Hills, constituting a section of the terminal Trzcińsk morain. This area extends along the subglacial valley from the village of Mętno in the north to the town of Moryn in the south and is distinctly elongated over a distance of approx. $4 \mathrm{~km}$.

According to the physico-geographical division of Poland (KondRacki 2002), the Moryńskie Hills are located in the macroregion of Pojezierze $\mathrm{Za}$ chodniopomorskie (314.4), mesoregion of Pojezierze Myśliborskie (314.41). A characteristic feature of the area around Moryn is a series of morains of the Myślibórz stage, running from Kostrzynek/Oder 


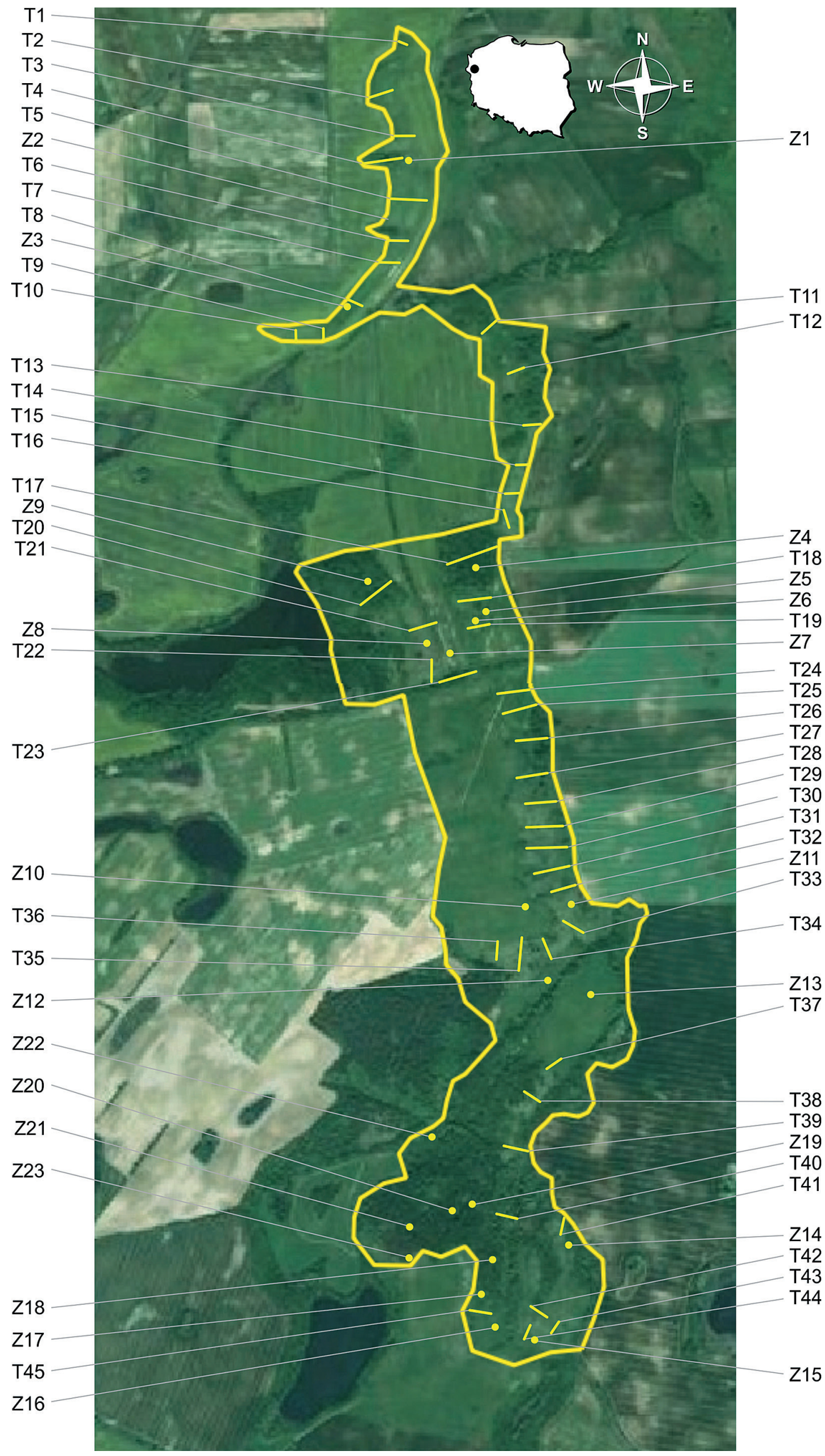

Fig. 1. Distribution of transects and phytosociological relevés of the Moryńskie Hills (transects are marked in yellow, phytosociological records in green, boundaries of the study area in red) 
through Myślibórz to Barlinek. As a consequence of the entire glaciation process, diverse land forms were created (BorówKA et al. 2004). The land relief is very rich, with predominant hilly and undulating morain plateaux (KONDRACKI 2002).

The Moryn Morain in very few places exceeds the height of $90 \mathrm{~m}$ a.s.l., on average reaching from 60 $\mathrm{m}$ to $70 \mathrm{~m}$ a.s.l. Altitudes above ground levels range from $20 \mathrm{~m}$ to over $40 \mathrm{~m}$ and such a diversification in altitude results in an impressive variation of landscape. West of Moryn in the area of Cedynia the morain hills reach much greater altitudes of up to 160 $\mathrm{m}$ a.s.l. (KoNDRACKI 2002), with the highest hill in the area, Zwierzyniec in the Puszcza Piaskowa forest, reaching $167 \mathrm{~m}$ a.s.l.

Soils found in the Moryńskie Hills are young deposits. They are highly diverse, which results mainly from the variation in the land relief, moisture content and lithogenic conditions. In the study area the predominant soils are glacial tills, their decayed deposits as well as glacial sands and gravels. On these morain sediments mainly brown and podzolic soils were formed, while slight depressions are filled with water-logged soils (MIECZYŃSKI 1947).

The investigated area has a specific topoclimate. Slopes and hillsides of the terminal morain hills, as well as the bottom of the subglacial valley form a microregion. In these locations the diurnal temperature ranges are considerable. Slopes with southern exposure are locations reached by the greatest amounts of sunshine, thus air temperature is much higher here.
Also the microclimate is more arid than on slopes with northern exposure. These conditions are typical of steppe regions, i.e. these areas are suitable places for the development and growth of xerothermic vegetation. In the morain hill zone precipitation ranges from 600 to $650 \mathrm{~mm}$ /year (BorówKA et al. 2004).

The Moryńskie Hills are areas of very attractive landscapes (Phot. 1). They comprise a mosaic of fields, grasslands, scrubs, forests and lakes. They are habitats for numerous animal species. They also provide favourable conditions for the development of a great number of plant taxa. Such an extensive richness of animate and inanimate nature resulted in a decision to include the area into the Cedyński Landscape Park, established in 1993.

The Moryńskie Hills, due to their natural value, were included into the Special Bird Refuge Ostoja Cedyńska (PLB320017) and Special Habitat Protection Area the Moryńskie Hills (PLH320055). The Hills are also elements of the ECONET network and serve the function of an international node area (LIRO 1998).

Within the framework of the geobotanical division of Poland (Matuszkiewicz 1993) the area (Fig. 2) is located in the Pomeranian Divide (A), the Szczecin Region (A.3), the Myślibórz District (A.3.2), in the Lubiechów Sub-district (A.3.2.d). This region comprises lake disticts with the predominance of Pomeranian beech forest landscape. Moreover, there are xerothermic oak forests and steppe grassland communities, beech-oak forests (Fago-Quercetum with

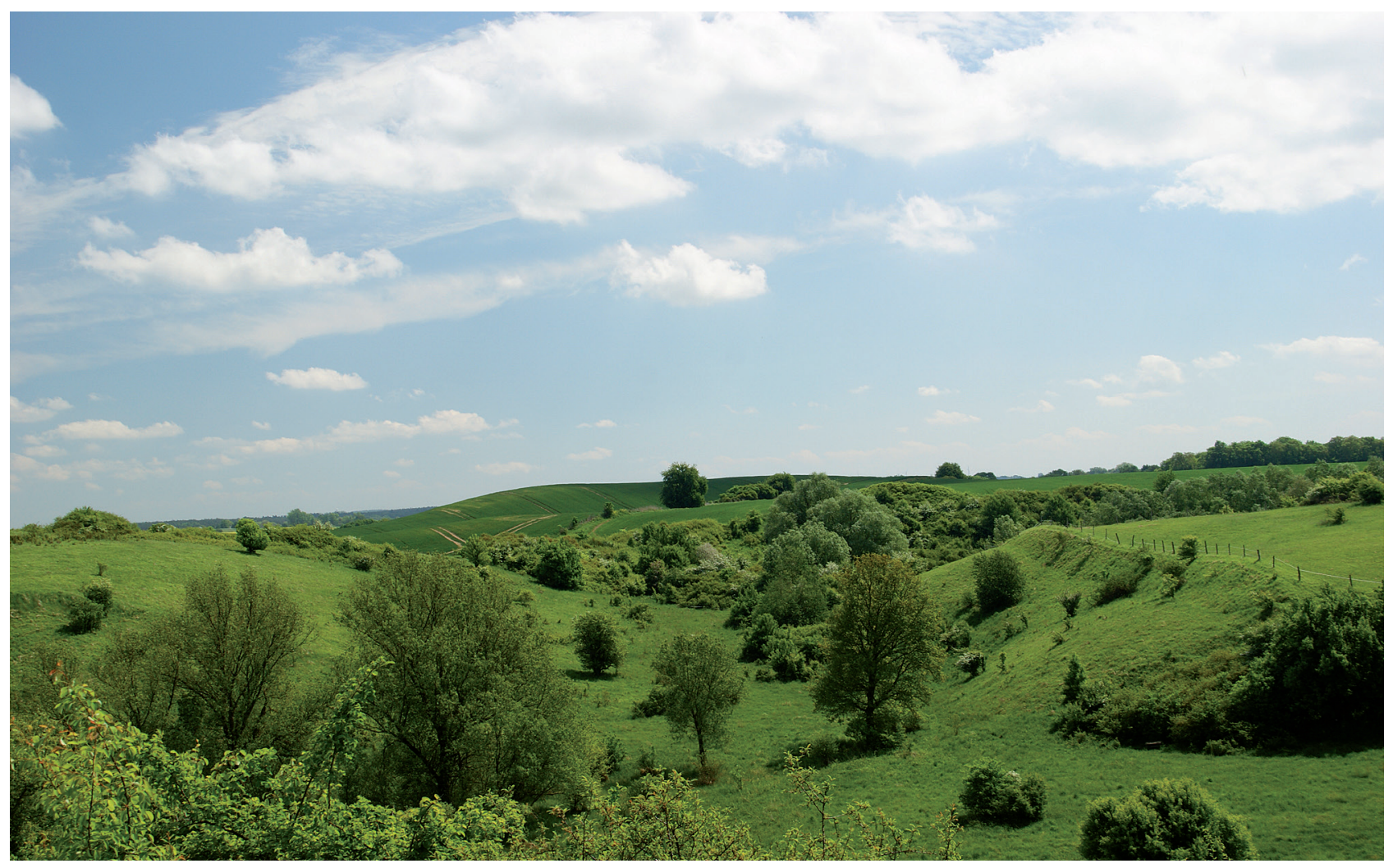

Phot. 1. Varied young glacial landscape of the Moryń Morain (phot. M. Kagan) 


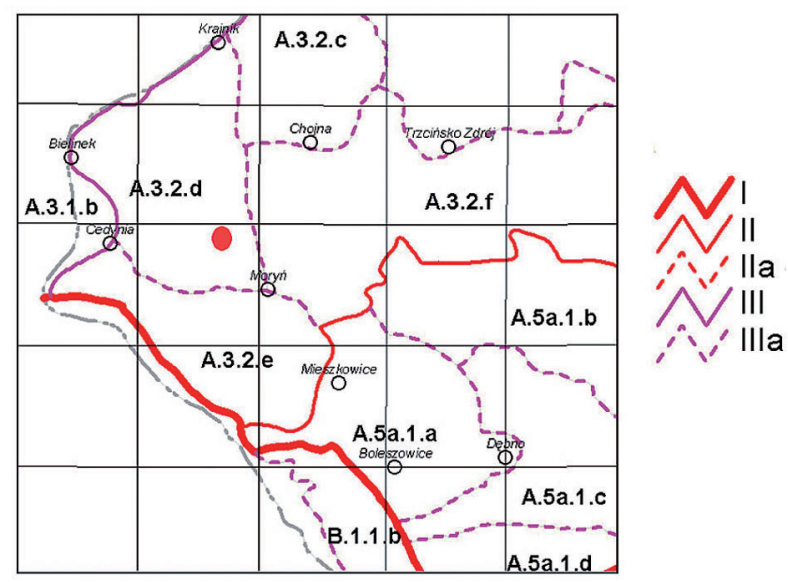

Fig. 2. Location of the Moryńskie Hills within the geobotanical division of Poland (MATUSZKIEwICZ 1993), the red dot denotes the study area; I - divides, II - region, IIa - sub-region, III - district, IIIa - sub-district. Source: http://globus.igipz.pan.pl/geoekoklimat/roslinnosc/regiony_mapa/B1_region.png; 28.03.2013 r.

Lonicera periclymenum) and Atlantic riverside carrs of the association Carici remotae-Fraxinetum.

The Moryńskie Hills do not show any considerable variation of the potential natural vegetation. In the study area two cartographic units of potential natural vegetation were distinguished (MATUSZKIEWICZ 2008). The geratest share in the total area is found for the community of potential fertile lowland beech forest Galio odorati-Fagetum. A smaller area is covered by non-forest communities of specific habitats, i.e. steppe xerothermic grassland Festucetalia valesiacae.

The predominant types of habitats found in the Moryńskie Hills are semi-natural habitats: swards, meadows, pastures, in-field small water bodies and wetlands, as well as multi-species scrubs and forests. Such a considerable variation is a consequence of land relief and to a limited extent - extensive herding. Forests account for $6 \%$ area of the Hills, while the rest is unforested area. On steep morain slopes xerothermic grasslands are found most frequently, with ocassional riparian forest Violo odoratae-Ulmetum minoris. Xerothermic grasslands frequently border with meadows from the Arrhenatherion alliance, usually found in plains of limited slope. Fresh meadows with a high share of xerothermic species occupy $14 \%$ area of the Moryńskie Hills. In drainless hollows in the examined area eutrophic small water bodies are frequently found. Associations with water lilies are found in bigger lakes. Xerothermic grasslands cover the area of approx. 50 ha, i.e. $9 \%$ area of the study (Natura 2000 SFD). In the region of Mętno and Dolsk the hills are covered with numerous xerothermic grassland communities with Stipa capillata, while Stipa joannis was found in several localities. Interesting grassland plants of the Moryńskie Hills include also Campanula sibirica and C. bononiensis, Melampyrum arvense, Antheri- cum liliago and Stachys recta. On a slope located east of Lake Górka in the spring you may find flowering Pulsatilla vernalis (JERMACZEK et al. 2005). Grasslands with dominant Stipa capillata prefer soils with a proportion of clay and with a greater amounts of humus. They typically cover slopes and hillsides of southern and western exposure, being found rarely on slopes with eastern exposure. Grasslands with dominant Brachypodium pinnatum are relatively common (JERMACZEK et al. 2005). The Moryńskie Hills have an abundance of grassland phytocenoses with Brachypodium pinnatum, frequently accompanied by xerothermic species, e.g. Campanula sibirica and Anthericum liliago.

\section{MATERIALS AND METHODS}

Field studies were conducted in two vegetation seasons in 2012 and 2013. The focus was on forest and scrub communities as well as permanent grassland and to a lesser degree on reed rush communities. In the study area of approx. $4 \mathrm{~km}$ in length a total of 45 transects were established. Transects were located at every $100 \mathrm{~m}$, omitting areas covered by arable fields. Outside the transects a total of 23 relevés were established applying the generally adopted method of Braun-BlanQuet (1964). Transects and relevés were selected so that they adequately characterised the diversity of plant communities in the study area. A seven-point scale was adopted in order to determine the numbers of taxa found both in floristic lists of the transects and in relevés. The location of each transect and relevé was marked on the map (1:5000 Google Earth map).

The nomenclature of individual plant species was adopted after Mirek et al. (2002), while the phytosociological nomenclature of communities was adopted after MatuszKiEwicz (2008).

In order to determine the existing life forms of plants, the system proposed by RAUNKIAER (1905) was applied, which classifies plants according to the distribution and manner of protection of dormant buds in the unfavourable season of the year. The study included the following basic units: megaphanerophytes, nanophanerophytes, woody chamaephytes and herbaceous chamaephytes, hemicryptophytes, geophytes, hydrophytes and therophytes. A characteristic of species in terms of the geo-historical classification was conducted according to the concept proposed by THELLUNG (1915). Species of native plants were distinduished, including non-synanthropic spontanophytes (Sn) and apophytes (Ap) as well as alien species: archeophytes (Ar), kenophytes $(\mathrm{Kn})$ and ephemerophytes (Ef). Flora was also analysed in terms of the share of legally protected species (RozPoRZĄDZENIE... 2012, Ordinance of the Minister of the Environment of 20 January 2012 on species of wild growing plants covered by legal protection), rare and threatened species (KAźMIERCZAKOWA \& ZARZYCKI 
2001, ŻuKowsKi \& JACKowiak 1995, Attachment II to the Dyrektywa..., Directive of the EEC Council 92/43/EWG) and species of ancient woodlands suggesting long and constant existence of forest sites in this area (Peterken 1974, Dzwonko 2007).

\section{RESULTS}

\section{CHARACTERISTICS OF FLORA}

In the Moryńskie Hills in patches of relevés and transects (Fig. 1) a total of 186 taxa of vascular plants were found (Attachment Table 6). The recorded species belong to 47 families, of which the most numerously represented are grasses Poaceae (29 species). Grasses include 21 genera, of which the genus Festuca (4 species) was found most frequently, while the genera Poa, Brachypodium, Calamagrostis, Deschampsia and Phleum were represented by two species each. Another familiy represented by numerous species was Asteraceae, of which 16 genera and 21 species were recorded. The genus Centaurea is represented by three species, while three other genera were represented by two species: Cirsium, Chrysanthemum and Erigeron. A rich family comprising 18 species is the family Fabaceaee. Trifolium is a numerous family, represented by five species. The genera Medicago, Melilotus and Vicia have two species each. Another family, rich in species, is the family Rosaceae (14 representatives), of which the most numerous genera are Filipendula, Geum and Potentilla (with 2 species each). A relative abundant group comprises species from the family Lamiaceae, which two genera Ajuga and Stachys have two representatives each. Another family represented this time by 10 species is Caryophyllaceae. There are seven genera, of which the most numerous are Silene (3 species) and Stellaria (2 species) (Fig. 3).
In the flora of the Hills 20 families are represented by single species.

Analysis of geo-historical groups of species showed that the native taxa are most numerous, accounting for $92 \%$ flora. The greatest share in theis groups was reported for apophytes (70\%). Non-synathropic spontaneophytes constitute $22 \%$ analysed species. Only $8 \%$ are alien species, of which the most abundant group is composed of kenophytes (Fig. 4). One taxon was recorded among ephemerophytes. Such a high number of native species indicates a natural character of flora found in the Moryńskie Hills.

It results from the analysis of life forms according to Raunkiaer (Fig. 5) that hemicryptophytes are the dominant group of plants, accouting for $61 \%$ flora in the Hills. Annual plants, as therophytes (13\%) and geophytes (10\%), are less abundant. The other groups do not play any greater role in the study area. Overall they constitute $16 \%$ of all species in the study area.

In the Moryńskie Hills a total of nine legally protected species were recorded. The group of wild plants found in the area and covered by strict protection (RozPoRZĄDZENIE... 2012, Ordinance of the Minister of the Environment of 5 January 2012 protection of plant species, the Journal of Law Dziennik Ustaw 2012) comprises four species: Anthericum liliago, Campanula sibirica, Centaurium erythraea and Stipa capillata. Among the five species three require active protection: Campanula sibirica, Anthericum liliago and Stipa capillata. Anthericum liliago is found only in one locality, which is a slope with western exposure, descending towards the eastern shore of Lake Górka. This site has only several specimens of this species. The four other taxa are found in gretear numbers and in more localities. Four taxa found in the study area have the status of species under partial protection:

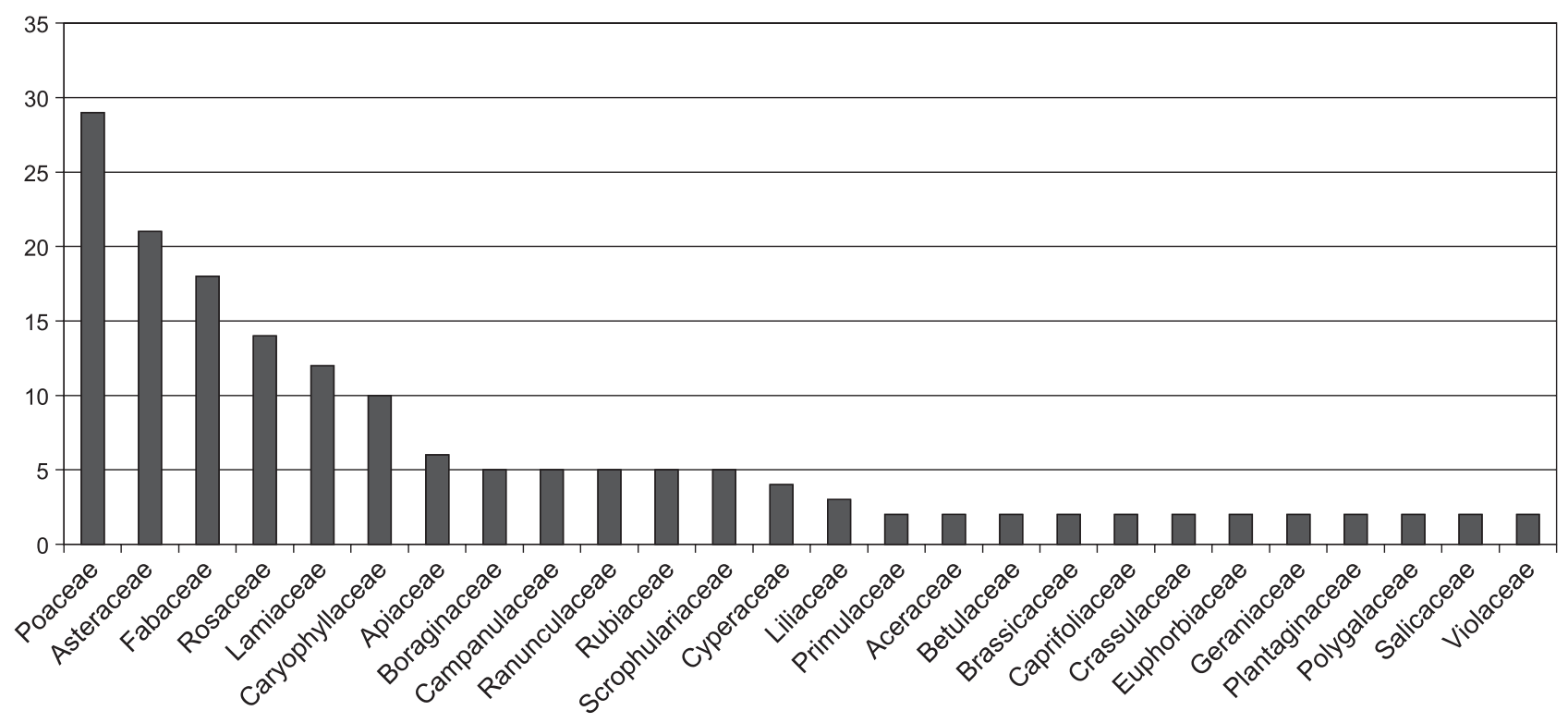

Fig. 3. Numbers of recorded species in individual families 


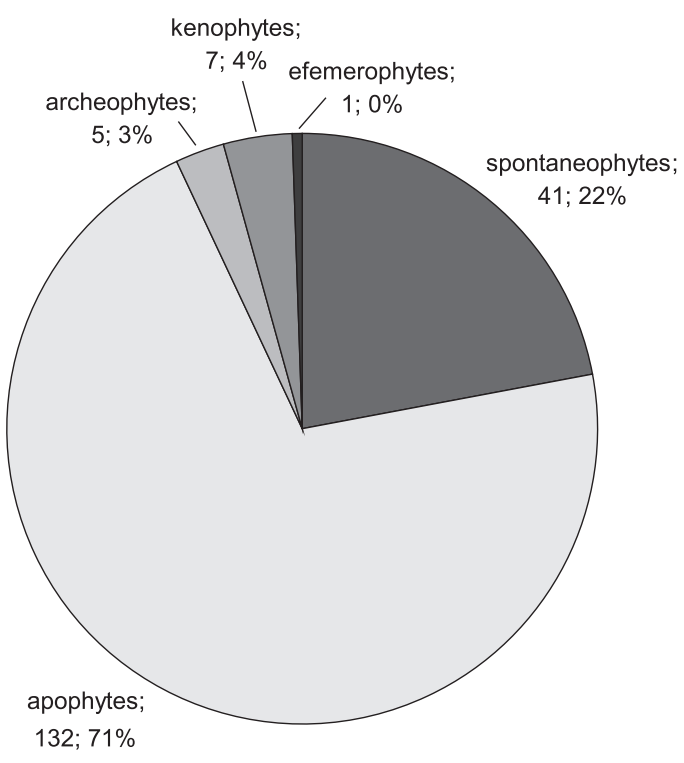

Fig. 4. Spectrum of geo-historical groups of species found in the study area

Helichrysum arenarium, Primula veris, Viburnum opulus and Galium odoratum. In the analysed communities one species from the Polish red book of plants was reported (KAźMIERCZAKOWA \& ZARZYCKI 2001). It is Anthericum liliago. This species was classified as vulnerable (VU). Among rare and threatened species in the Western Pomerania (ŻUKOWSKI \& JACKOWIAK 1995) we have eight taxa, of which Acer campestre is classified as a rare species (R) and one, Thalictrum simplex, as unspecified (data deficient). The list of vulnerable species $(\mathrm{V})$ in the study area comprises six taxa (Anthericum liliago, Campanula sibirica, Laserpitium prutenicum, Melampyrum arvense, Stachys recta, Stipa capillata). Among all the plants from Attachment II of the Directive of the EECCouncil 92/43/EEC (DYREKTYWA... 1992), four taxa were reported in the study area. This group includes Anthericum liliago, Campanula sibirica, Stachys recta and Stipa capillata. The analysed flora comprises 11 species of ancient woodlands (Dzwonко 2007). They are found mainly in riparian forests and thickets of the study area (Aegopodium podagraria, Ajuga reptans, Brachypodium silvaticum, Campanula trachelium, Dryopteris filix-mas, Euphorbia dulcis, Galium odoratum, Geum urbanum, Impatiens noli-tangere, Poa nemoralis, Stellaria nemorum).

\section{CHARACTERISTICS OF COMMUNITIES}

Vegetation of the Moryńskie Hills is highly varied. A mosaic of soils, large numbers of dranless small thawed-out water bodies and the varied young glacial land relief all contribute to the fact that within a limited area of the Hills adequate conditions are provided for both forest, shrub as well as different non-forest communities. In the study area four complexes of

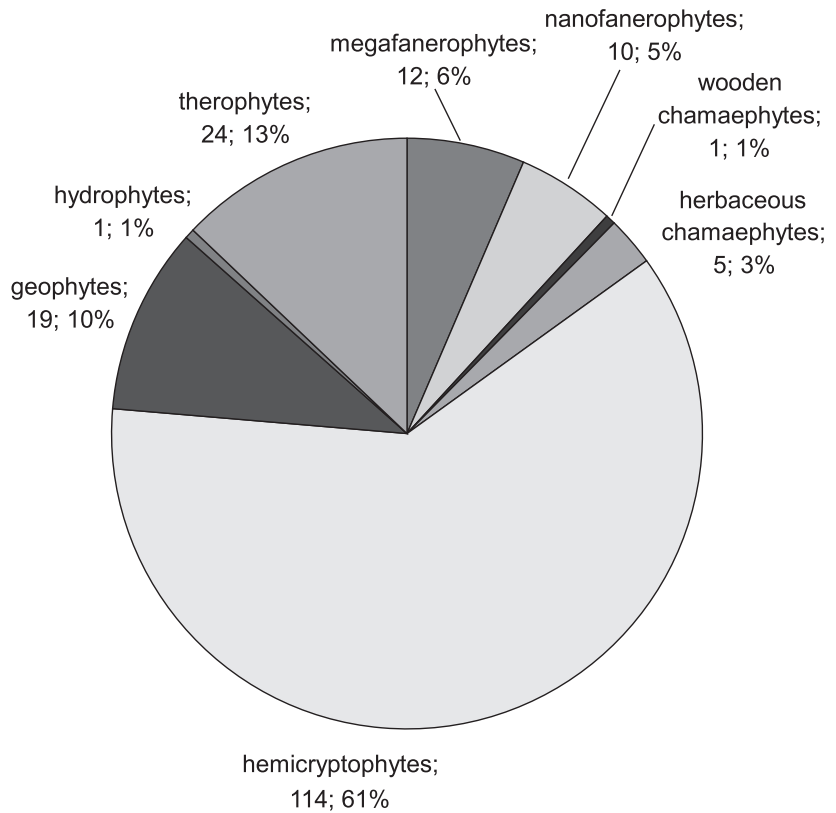

Fig. 5. Spectrum of life forms of species

plant communities are distinguished: forest, shrub, xerothermic grassland, as well as meadows and pastures.

In the Moryńskie Hills, mainly in the southern part, riparian forest habitats are found (Table 1). Their area is relatively large. They are forests overgrowing steep and high slopes. Smaller phytocenoses of riverside carrs are found also in the central part of the Hills, mainly on the slopes adjacent to Lake Górka. Riparian forests grow here on fertile soils formed on glacial tills and to a lesser degree on glacial sands, rich in calcium carbonate. Riparian forests are characterised here by a well developed shrub layer. The vegetation is considerably affected by periodical droughts in the summer period and strong surface runoff of rainwater. The development of the herbaceous layer to a considerable degree depends on light conditions and it mainly comprises hemicryptophytes, with geophytes being much less frequent.

The characteristic species of the Querco-Fagetea class found in the Hills include Acer campestre, Aegopodium podagraria, Fraxinus excelsior, Brachypodium sylvaticum and Poa nemoralis. The upper layer of trees is typically composed of Ulmus laevis, while only in phytocenoses in two relevés no. 21 and 22 Ulmus laevis was found in the shrub layer. In two phytocenoses (relevés 20 and 19) Betula pendula is found in the upper layer, while in the phytocenosis documented by relevé $19 \mathrm{~B}$. pendula solely forms the upper layer. The forest floor vegetation cover comprises species associated with the riparian elm association Violo odoratae-Ulmetum minoris. These include Viola odorata (relevés 4, 9, 18, 22), Campanula persicifolia (relevé 4) and Campanula rapunculoides (relevés 4, 9, 18). Relatively frequent species in the forest floor cover include Brachypodium sylvaticum 
Table 1. Riparian habitat communities

\begin{tabular}{|c|c|c|c|c|c|c|c|}
\hline Successive number of relevé & 1 & 2 & 3 & 4 & 5 & 6 & 7 \\
\hline Field number of relevé & 22 & 4 & 9 & 18 & 20 & 19 & 21 \\
\hline Date & 31.05 .2013 & 24.06 .2012 & 24.06 .012 & 01.06 .2013 & 02.06 .2013 & 01.06 .2013 & 02.06 .2013 \\
\hline Cover of tree layer a (\%) & 80 & 80 & 90 & 90 & 70 & 60 & 60 \\
\hline Cover of shrub layer b (\%) & 5 & 10 & 5 & 10 & - & 70 & 50 \\
\hline Cover of herb layer c (\%) & 70 & 50 & 40 & 50 & 90 & 60 & 70 \\
\hline Area of relevé $\left(\mathrm{m}^{2}\right)$ & 200 & 200 & 200 & 200 & 200 & 200 & 200 \\
\hline Number of species in relevé & 15 & 18 & 15 & 19 & 15 & 27 & 19 \\
\hline \multicolumn{8}{|l|}{ ChCl. Vaccinio-Piceetea } \\
\hline Pinus sylvestris a & - & - & - & - & - & 5.5 & 5.5 \\
\hline \multicolumn{8}{|l|}{ ChCl. Querco-Fagetea } \\
\hline Ulmus laevis $\mathrm{a} / \mathrm{b}$ & $1+$ & $5.5 /$ & $5.5 /$ & $3.3 /$ & + & 1.1 & $/ 3.2$ \\
\hline Alnus glutinosa a & 5.5 & - & - & - & - & - & - \\
\hline Fraxinus excelsior $\mathrm{a} / \mathrm{b}$ & - & - & $\mathrm{r} /$ & - & - & $/ 4.4$ & - \\
\hline Acer pseudoplatanus a & - & 3.1 & - & - & - & - & - \\
\hline Brachypodium sylvaticum & 2.2 & 1.2 & 3.1 & 5.5 & 4.4 & 2.2 & - \\
\hline Viola odorata & 2.2 & 4.5 & 3.2 & 2.2 & - & - & + \\
\hline Impatiens noli-tangere & 1.2 & 3.3 & + & - & - & - & - \\
\hline Dryopteris filix-mas & 2.1 & 1.1 & - & 1.1 & - & - & - \\
\hline Primula veris & - & 1.2 & - & 2.2 & - & 2.2 & 1.1 \\
\hline Poa nemoralis & - & - & - & - & - & 1.1 & 3.3 \\
\hline Galium sylvaticum & - & - & - & - & 1.1 & 1.1 & - \\
\hline Campanula persicifolia & - & 1.1 & - & - & - & - & + \\
\hline Galium odoratum & - & - & 1.2 & - & - & - & - \\
\hline Quercus petraea a & - & - & - & 2.1 & - & - & - \\
\hline Quercus petraea & - & - & - & - & + & - & + \\
\hline Euphorbia dulcis & - & - & - & - & - & + & - \\
\hline Stellaria nemorum & - & - & - & - & - & - & + \\
\hline \multicolumn{8}{|l|}{ ChCl. Epilobietea angustifolii } \\
\hline Betula pendula a & - & - & - & 2.1 & 5.5 & - & - \\
\hline Sambucus nigra $\mathrm{b}$ & + & 1.1 & + & - & - & - & + \\
\hline Fragaria vesca & - & - & - & - & - & 1.1 & - \\
\hline \multicolumn{8}{|l|}{ ChCl. Rhamno-Prunetea } \\
\hline Rosa canina $\mathrm{b}$ & - & - & - & - & - & + & + \\
\hline Acer campestre & - & - & - & + & - & - & - \\
\hline Crataegus laevigata b & - & - & - & 1.1 & - & - & + \\
\hline Berberis vulgaris $\mathrm{b}$ & - & - & - & + & - & + & - \\
\hline Rhamnus cathartictus & - & - & - & 1.1 & - & - & - \\
\hline \multicolumn{8}{|l|}{ ChCl. Festuco-Brometea } \\
\hline Ajuga genevensis & - & - & - & 1.1 & 1.1 & 2.2 & - \\
\hline Brachypodium pinnatum & - & - & - & - & - & 1.1 & - \\
\hline \multicolumn{8}{|c|}{$\begin{array}{l}\text { ChCl. Koelerio glaucae-Corynephore- } \\
\text { tea canescentis }\end{array}$} \\
\hline Rumex acetosella & - & - & - & - & - & - & + \\
\hline \multicolumn{8}{|l|}{ ChCl. Molinio-Arrhenatheretea } \\
\hline Dactylis glomerata & - & - & - & 1.1 & 1.1 & 3.3 & 5.5 \\
\hline Laserpitium prutenicum & - & - & - & - & 1.1 & - & - \\
\hline
\end{tabular}


Table 1. cont.

\begin{tabular}{|c|c|c|c|c|c|c|c|}
\hline Successive number of relevé & 1 & 2 & 3 & 4 & 5 & 6 & 7 \\
\hline Ranunculus repens & - & - & - & - & 1.1 & - & - \\
\hline Vicia cracca & - & - & - & - & 1.1 & 1.1 & - \\
\hline Plantago major & - & - & - & - & - & 2.2 & - \\
\hline Cynosurus cristatus & - & - & - & - & - & 1.2 & - \\
\hline Knautia arvensis & - & - & - & - & - & + & - \\
\hline Plantago lanceolata & - & - & - & - & - & + & - \\
\hline Ranunculus acris & - & - & - & - & - & + & - \\
\hline \multicolumn{8}{|l|}{ ChCl. Phragmitetea } \\
\hline Peucedanum palustre & 1.2 & - & - & - & - & - & - \\
\hline \multicolumn{8}{|l|}{ ChCl. Artimisietea vulgaris } \\
\hline Geum urbanum & 2.1 & 2.2 & 1.2 & 1.1 & 3.2 & 1.1 & - \\
\hline Chaerophyllum temulum & 1.1 & 1.2 & 1.2 & - & 1.1 & + & 1.1 \\
\hline Aegopodium podagraria & 1.1 & - & - & - & - & - & - \\
\hline Geranium robertianum & 2.2 & 2.2 & 2.2 & 1.1 & - & 1.1 & 1.2 \\
\hline Galium aparine & 2.2 & + & - & - & - & - & - \\
\hline Alliaria petiolata & - & 1.1 & + & - & - & - & - \\
\hline Rubus caesius & - & - & - & 3.3 & - & 3.3 & - \\
\hline Moehringia trinervia & - & 1.2 & - & - & - & - & - \\
\hline Urtica dioica & 1.1 & - & - & - & - & - & - \\
\hline Lamium maculatum & - & - & - & - & - & - & 1.1 \\
\hline \multicolumn{8}{|l|}{ ChCl. Stellarietea mediae } \\
\hline Odontites verna & - & + & 1.2 & - & - & - & - \\
\hline Lapsana communis & - & - & + & - & - & - & - \\
\hline \multicolumn{8}{|c|}{ ChCl. Trifolio-Geranietea sanguinei } \\
\hline Agrimonia eupatoria & 1.1 & - & - & 1.1 & 1.1 & - & - \\
\hline Campanula rapunculoides & - & + & 1.1 & + & - & - & - \\
\hline \multicolumn{8}{|l|}{ Others } \\
\hline Robinia pseudacacia a/b & - & $1+$ & +1 & - & - & - & $1+$ \\
\hline Lolium multiflorum & - & - & - & - & 1.1 & 1.1 & - \\
\hline Pyrus communis b & - & - & - & 1.1 & + & 1.1 & - \\
\hline Silene chlorantha & - & - & - & - & - & - & 1.1 \\
\hline Euphorbia esula & - & - & - & - & - & + & - \\
\hline Veronica chamaedrys & - & - & - & - & - & - & + \\
\hline
\end{tabular}

forming large patches (relevés 4, 9, 18, 19, 20, 22) and Geum urbanum (relevés 4, 9).

Moreover, deformed phytocenoses were also found, in which the upper tree layer was formed by Pinus sylvestris. This form of degeneration, pine overgrowing (pinetyzation), is observed in patches of relevés 19 and 21 . They are stands originating from the period after World War II, when intenive afforestation was practiced, frequently using scot pine. In the plot documented by relevé 21 strong regeneration with Fraxinus excelsior and typical riparian species are found in the undergrowth.

Mesophilous scrub communities in the study area form relatively large patches (Table 2). They are mostly thickets found in the open spaces, to a less- er extent being shrub communities of forest edges (Phot. 2). Shrubs growing here are formed by communities with domed canopies, in which branches of individual specimens are greatly entangled. Mesophilous thickets comprise primarily shrub species from the Rhamno-Prunetea class: Prunus spinosa, Crataegus laevigata, Rhamnus cathartica and Rosa canina. The most abundant is Prunus spinosa, a species mostfrequently forming Rubo fruticosi-Prunetum spinosae shrub thickets overgrowing the Moryńskie Hills. Prunus spinosa predominated in two patches (relevés 3 and 17). A frequent species found in the mesophilic shrubs is also Crataegus laevigata, which in places forms single-species shrub thickets. The structure of Rubo fruticosi-Prunetum spinosae is very dense and 
Table 2. Communities of the Rhamno-Prunetea class

\begin{tabular}{|c|c|c|}
\hline Successive number of relevé & 1 & 2 \\
\hline Field number of relevé & 3 & 17 \\
\hline Date & 20.06 .2012 & 01.06 .2012 \\
\hline Cover of shrub layer b (\%) & 60 & 85 \\
\hline Cover of herb layer c (\%) & 80 & 50 \\
\hline Area of relevé $\left(\mathrm{m}^{2}\right)$ & 150 & 150 \\
\hline Number of species in relevé & 16 & 14 \\
\hline \multicolumn{3}{|l|}{ ChCl. Rhamno-Prunetea } \\
\hline Prunus spinosa $\mathrm{b}$ & 3.2 & 5.5 \\
\hline Crataegus laevigata $\mathrm{b}$ & 2.1 & 2.2 \\
\hline Rhamnus cathartica b & 1.1 & - \\
\hline Rosa canina & & $\mathrm{r}$ \\
\hline \multicolumn{3}{|l|}{ ChCl. Querco-Fagetea } \\
\hline Quercus petraea $\mathrm{b}$ & - & + \\
\hline Campanula trachelium & $\mathrm{r}$ & - \\
\hline \multicolumn{3}{|l|}{ ChCl. Festuco-Brometea } \\
\hline Brachypodium pinnatum & 3.2 & - \\
\hline Phleum phleoides & - & 2.2 \\
\hline \multicolumn{3}{|c|}{ ChCl. Trifolio-Geranietea sanguinei } \\
\hline Agrimonia eupatoria & 1.1 & - \\
\hline Galium verum & - & 1.1 \\
\hline Coronilla varia & + & - \\
\hline \multicolumn{3}{|l|}{ ChCl. Molinio-Arrhenatheretea } \\
\hline Dactylis glomerata & - & 3.3 \\
\hline Achillea millefolium & - & 1.1 \\
\hline Knautia arvensis & 1.1 & - \\
\hline Tragopogon pratensis & 1.1 & - \\
\hline Elymus repens & + & - \\
\hline Linum catharticum & + & - \\
\hline \multicolumn{3}{|c|}{ ChCl. Agropyretea intermedio-repentis } \\
\hline Falcaria vulgaris & + & + \\
\hline \multicolumn{3}{|l|}{ ChCl. Artemisietea vulgaris } \\
\hline Rubus caesius & 1.2 & + \\
\hline Geum urbanum & 1.1 & - \\
\hline Hypericum perforatum & + & - \\
\hline \multicolumn{3}{|l|}{ Others } \\
\hline Silene chlorantha & + & 1.1 \\
\hline Lolium multiflorum & - & 1.1 \\
\hline Potentilla recta & - & 1.1 \\
\hline Pyrus communis b & - & + \\
\hline
\end{tabular}

forms a strongly compacted shrub community. The composition of the undergrowth vegetation cover is varied, with sward, meadow, ruderal and herbs of forest edge communities species. A considerable effect on the shrubs in the forest floor cover, which is relatively poorly developed, is observed for neighbouring communities, of which plants penetrate to shrub phytocenoses.
Mesophilous shrubs of the Hills are poorer communities in terms of their floristic composition. Two of the analysed plots include total of 25 plant species. Such a small number of species is connected with considerable large coverage of bushes, which reduces the amount of light penetrating to the bottom of the shrub layer. This results in the formation of a low coverage and poor herbaceous layer. 


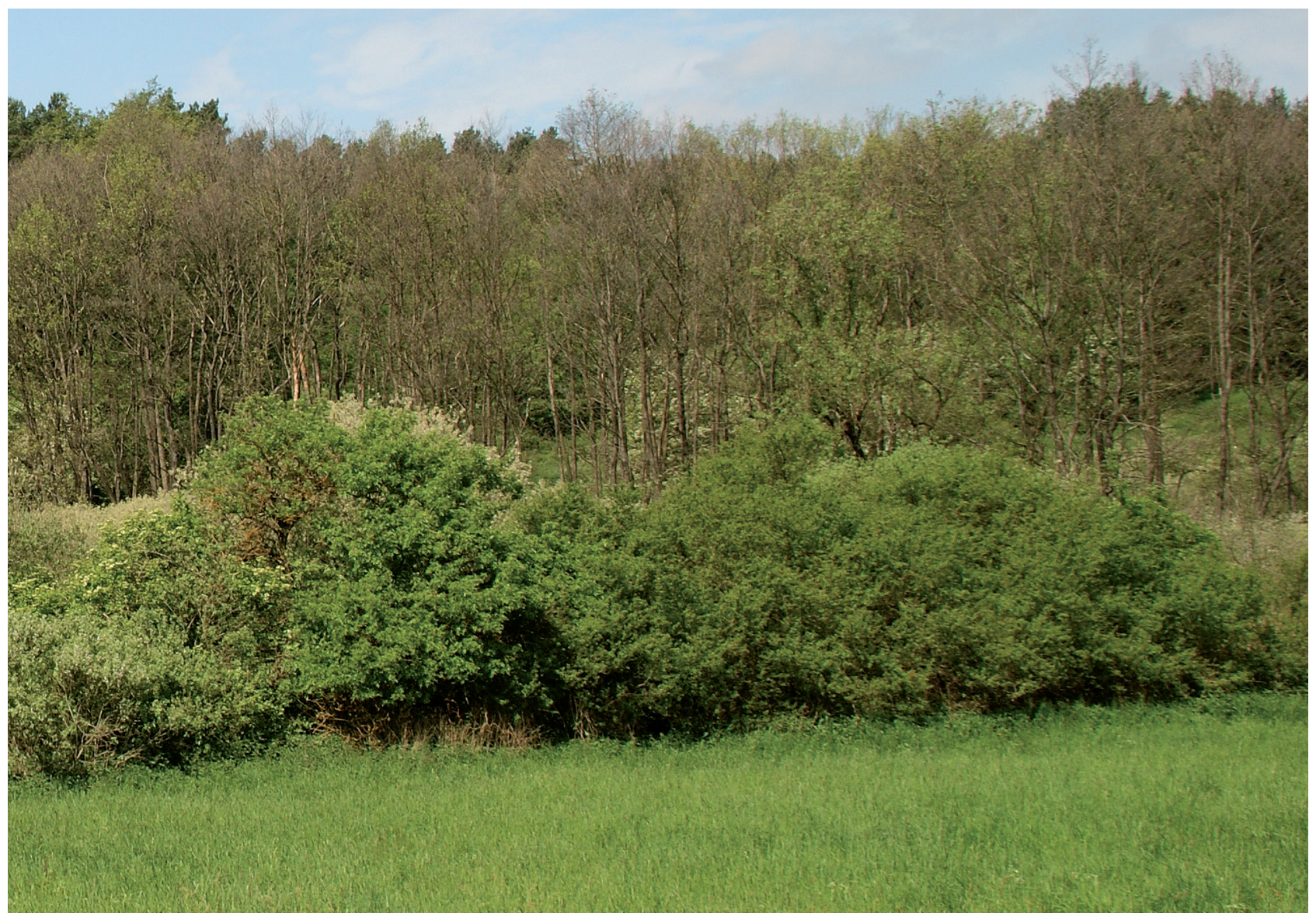

Phot. 2. Blackthorn shrubs, nesting ground for Lanius collurio (phot. M. Kagan)

Thickets play a very important role in the landscape, they form in-field wind-break belts, while thickets are refuges and feed bases for animals. In the Moryńskie Hills there is a large population of Lanius collurio, which finds nesting space in shrubs and may thrust their prey onto shrub thorns.

A considerable area of the Moryńskie Hills are areas overgrown with xerothermic vegetation (Table 3 ). Communities of the Festuco-Brometea class are found on steep, strongly insolated, rapidly heating slopes. These swards are found most frequently on brown soils formed on glacial sands and glacial tills. Communities of xerothermic grassland have the character of secondary communities, which survived mainly thanks to herding management. At present no agricultural acitivty is conducted there. For this reason in many places grasslands are replaced in the course of secondary succession and are overgrown by shrubs, mainly blackthorn and hawthorns. An example may also be provided by the patches documented by relevé no. 11, where Scot pine seedlings were found. Communities from the Festuco-Brometea class are characterised by an extremely rich species composition, with rare and protected species frequently found. Most often they are overgrown by xerothermic species, while mesophilic species are foud very rarely.

Xerothermic sward is characterised by a high esthetic value. The colour of grassland changes throughout the vegetation season, with yellow and purple predominating. The characteristic species of the Festuco-Brometea class include Ajuga genevensis, Anthericum liliago, Anthyllis vulneraria, Artemisia campestris, Brachypodium pinnatum, Carlina vulgaris, Dianthus carthusianorum and Phleum phleoides. Xerothermic grasslands were documented on 8 relevés, with an average of 18 species of vascular plants recorded per relevé (from 12 to 23 taxa). Overall in eight phytocenoses a total of 61 plant species were identified.

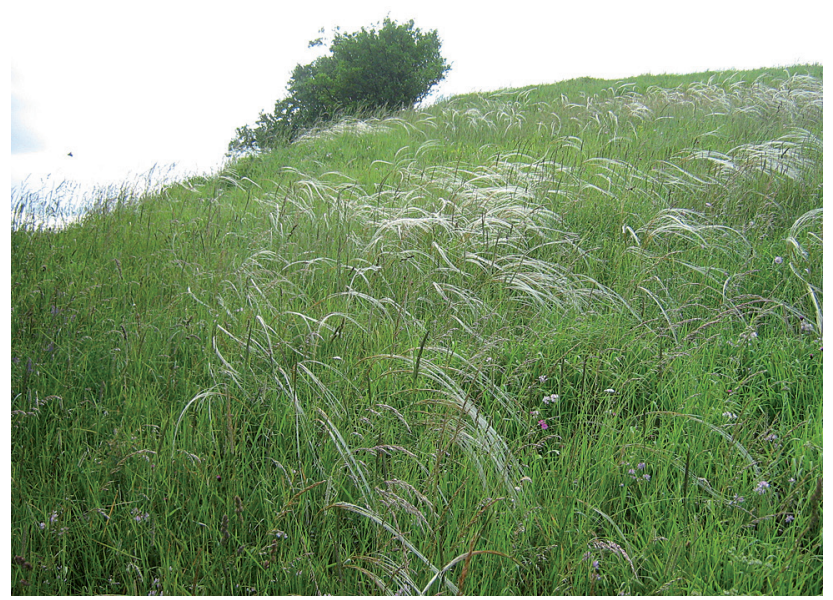

Phot. 3. Phytocenon of sward with Stipa capillata found in the northern part of the study area (phot. M. Kagan) 
Table 3. Communities of the Festuco-Brometea class

\begin{tabular}{|c|c|c|c|c|c|c|c|c|}
\hline Successive number of relevé & 1 & 2 & 3 & 4 & 5 & 6 & 7 & 8 \\
\hline Field number of relevé & 11 & 2 & 8 & 5 & 23 & 7 & 1 & 6 \\
\hline Date & \multicolumn{8}{|c|}{ 31.05.2013 14.06.2012 30.06.2012 25.06.2012 01.06.2013 30.06.2012 14.06.2012 25.06.2012 } \\
\hline Cover of herb layer c (\%) & 100 & 100 & 90 & 85 & 80 & 75 & 70 & 85 \\
\hline Area of relevé $\left(\mathrm{m}^{2}\right)$ & 25 & 25 & 25 & 25 & 25 & 25 & 25 & 25 \\
\hline Number of species in relevé & 23 & 18 & 25 & 15 & 16 & 23 & 14 & 12 \\
\hline \multicolumn{9}{|l|}{ ChCl. Festuco-Brometea } \\
\hline Brachypodium pinnatum & 3.3 & 3.3 & 2.2 & 1.2 & - & - & - & - \\
\hline Stipa capillata & - & - & 1.2 & 2.2 & 3.3 & 2.3 & - & - \\
\hline Phleum phleoides & - & - & - & 1.2 & 2.2 & 3.3 & - & 3.2 \\
\hline Galium verum & 2.2 & + & + & - & + & 1.2 & - & - \\
\hline Melampyrum arvense & 2.2 & - & + & - & - & 1.2 & - & - \\
\hline Thymus pulegioides & 1.2 & - & - & - & - & - & 1.1 & - \\
\hline Artemisia campestris & - & - & + & - & - & + & 2.1 & - \\
\hline Ajuga genevensis & 1.2 & - & - & - & - & - & - & - \\
\hline Anthyllis vulneraria & 1.2 & - & - & - & - & - & - & - \\
\hline Carlina vulgaris & 1.1 & - & - & - & - & - & - & - \\
\hline Anthericum liliago & - & - & $\mathrm{r}$ & - & - & - & - & - \\
\hline Campanula sibirica & $\mathrm{r}$ & - & - & - & - & - & - & - \\
\hline \multicolumn{9}{|c|}{ ChCl. Trifolio-Geranietea sanguinei } \\
\hline Coronilla varia & 1.2 & - & - & - & - & - & 1.2 & - \\
\hline \multicolumn{9}{|c|}{$\begin{array}{l}\text { ChCl. Koelerio glaucae-Corynephore- } \\
\text { tea canescentis }\end{array}$} \\
\hline Corynephorus canescens & - & 1.2 & 1.1 & 2.2 & 2.2 & + & - & 2.1 \\
\hline Sedum acre & - & - & - & - & - & 1.2 & + & - \\
\hline Trifolium arvense & - & - & + & - & 2.2 & - & - & - \\
\hline Silene otites & - & - & - & - & + & 2.2 & - & - \\
\hline Armeria elongata & - & + & - & - & + & - & + & - \\
\hline Rumex acetosella & - & + & + & - & - & + & - & - \\
\hline \multicolumn{9}{|l|}{ ChCl. Molinio-Arrhenatheretea } \\
\hline Achillea millefolium & - & + & - & 2.2 & 1.2 & 2.2 & - & 2.2 \\
\hline Avenula pubescens & - & 1.2 & 1.1 & 1.2 & - & 1.2 & - & - \\
\hline Briza media & 2.2 & 1.2 & 2.2 & - & - & - & + & - \\
\hline Centaurea jacea & 1.1 & + & + & + & - & 1.1 & - & - \\
\hline Leucanthemum vulgare & 1.1 & - & - & - & - & - & 2.2 & 1.1 \\
\hline Dianthus carthusianorum & - & + & - & - & 3.2 & 3.2 & - & - \\
\hline Knautia arvensis & 1.1 & - & + & - & - & + & - & - \\
\hline Linum catharticum & 1.2 & - & + & - & - & - & - & - \\
\hline Lotus corniculatus & 1.1 & - & + & - & - & - & - & - \\
\hline Plantago lanceolata & 1.2 & + & - & - & - & - & - & - \\
\hline Trifolium montanum & 1.2 & - & - & - & - & - & + & - \\
\hline Veronica longifolia & - & - & - & + & + & - & - & - \\
\hline Vicia cracca & - & - & - & + & - & + & - & - \\
\hline Festuca rubra & - & - & - & - & - & + & - & - \\
\hline Tragopogon pratensis & - & - & - & - & - & - & + & - \\
\hline \multicolumn{9}{|l|}{ ChCl. Epilobietea angustifolii } \\
\hline Fragaria vesca & - & 1.2 & 1.2 & 1.2 & - & - & - & 2.1 \\
\hline
\end{tabular}


Table 3. cont.

\begin{tabular}{|c|c|c|c|c|c|c|c|c|}
\hline Successive number of relevé & 1 & 2 & 3 & 4 & 5 & 6 & 7 & 8 \\
\hline Calamagrostis epigejos & - & - & - & 1.2 & - & - & - & - \\
\hline \multicolumn{9}{|c|}{$\mathrm{ChCl}$. Agropyretea intermedio-repentis } \\
\hline Falcaria vulgaris & - & - & - & - & - & - & 4.4 & 4.4 \\
\hline \multicolumn{9}{|l|}{ ChCl. Betulo-Adenostyletea } \\
\hline Calamagrostis arundinacea & - & 1.2 & 1.1 & - & - & + & - & - \\
\hline Leontodon hispidus & 1.2 & $\mathrm{r}$ & - & - & - & - & - & - \\
\hline \multicolumn{9}{|l|}{ ChCl. Nardo-Callunetea } \\
\hline Polygala vulgaris & - & - & - & - & - & - & - & 2.2 \\
\hline \multicolumn{9}{|l|}{ ChCl. Artemisietea vulgaris } \\
\hline Medicago sativa & + & - & 1.2 & 1.2 & - & - & - & - \\
\hline Hypericum perforatum & - & + & 1.2 & + & + & - & - & - \\
\hline Echium vulgare & - & - & - & - & - & + & - & 1.2 \\
\hline Potentilla argentea & - & - & - & - & 1.2 & - & - & - \\
\hline Rubus caesius & - & - & - & - & - & - & 1.1 & - \\
\hline Medicago lupulina & - & - & + & - & - & - & - & - \\
\hline Chaerophyllum temulum & - & - & - & + & - & - & - & - \\
\hline Linaria vulgaris & - & $\mathrm{r}$ & - & - & - & - & - & - \\
\hline \multicolumn{9}{|l|}{ ChCl. Stellarietea mediae } \\
\hline Orobanche serotina & - & - & 2.2 & - & - & - & 2.2 & 3.2 \\
\hline Chrysanthemum segetum & - & + & - & - & - & - & - & - \\
\hline \multicolumn{9}{|l|}{ ChCl. Vaccinio-Piceetea } \\
\hline Pinus sylvestris & + & - & - & - & - & - & - & - \\
\hline \multicolumn{9}{|l|}{ ChCl. Querco-Fagetea } \\
\hline Primula veris & 2.2 & - & + & - & - & - & - & - \\
\hline Euphorbia dulcis & - & - & - & - & - & - & - & + \\
\hline Campanula trachelium & $\mathrm{r}$ & - & - & - & - & - & - & - \\
\hline \multicolumn{9}{|l|}{ Others } \\
\hline Salvia pratensis & 2.2 & - & - & 1.1 & + & + & 1.2 & 2.2 \\
\hline Potentilla recta & - & - & - & 2.2 & 1.2 & 3.3 & - & - \\
\hline Sedum maximum & - & 4.3 & 1.2 & - & + & + & - & - \\
\hline Erigeron annuus & - & - & 1.2 & - & - & - & 1.1 & 1.1 \\
\hline Allium vineale & - & - & - & - & - & 1.1 & - & - \\
\hline Petrorhagia prolifera & - & - & - & - & + & + & - & - \\
\hline Ononis spinosa & - & - & + & - & - & - & - & - \\
\hline
\end{tabular}

In terms of the covered area Brachypodium pinnatum, Stipa capillata and Phleum phleoides predominated. The most interesting phytocenoses are those covered by large numbers of $S$. capillata (Phot. 3), which sometimes forms uniform light swards swaying in the wind. Patchas with S. capillata are most frequently found on very steep, strongly insolated slopes.

Corynephorus canescens and Salvia pratensis are permanent elements of the described xerothermic grasslands, which are found in almost every described plots. Species from the Molinio-Arrhenatheretea class are also frequent, although they do not cover large areas. Described phytocenoses were characterised by a relatively large herb layer cover, on average the cover amounting to over $85 \%$ relevé area. The lowest herb layer cover rate was observed in patches growing on very shallow and dry soils.

Communities from the Molinio-Arrhenatheretea class were formed primarily on more fertile habitats (Table 4). They are semi-natural pasture and meadow communities found on soils with various moisture levels. In the Moryńskie Hills they cover the greatest area and have a rich floristic composition (20 species). Characteristic species found in the study area include Alopecurus pratensis, Avenula pubescens, Festuca pratensis, Holcus lanatus, Phleum pratense, Plantago lanceolata, Poa pratensis, Trifolium pratense and Vicia cracca. 
Table 4. Communities of the Molinio-Arrhenatheretea class

\begin{tabular}{|c|c|c|c|c|}
\hline Successive number of relevé & 1 & 2 & 3 & 4 \\
\hline Field number of relevé & 13 & 10 & 16 & 12 \\
\hline Date & 31.05 .2013 & 31.05 .2013 & 01.06 .2013 & 31.05 .2013 \\
\hline Cover of herb layer c (\%) & 95 & 85 & 100 & 100 \\
\hline Area of relevé $\left(\mathrm{m}^{2}\right)$ & 25 & 25 & 25 & 25 \\
\hline Number of species in relevé & 19 & 17 & 23 & 18 \\
\hline \multicolumn{5}{|l|}{ ChCl. Molinio-Arrhenatheretea } \\
\hline Avenula pubescens & 4.4 & 1.1 & 3.3 & 4.4 \\
\hline Dactylis glomerata & 2.2 & 1.1 & 5.5 & 3.3 \\
\hline Plantago lanceolata & 2.1 & 2.1 & 1.1 & 1.1 \\
\hline Festuca pratensis & 1.1 & 1.2 & 1.1 & 1.1 \\
\hline Phleum pratense & 1.1 & 1.1 & 2.2 & 1.1 \\
\hline Trifolium repens & 2.2 & - & 2.2 & 2.2 \\
\hline Leucanthemum vulgare & 2.2 & 2.2 & - & 1.1 \\
\hline Deschampsia caespitosa & 2.2 & 1.2 & - & 2.2 \\
\hline Trifolium pratense & 1.2 & - & 1.1 & 1.1 \\
\hline Vicia cracca & 1.2 & 1.2 & 1.1 & - \\
\hline Alopecurus pratensis & 1.2 & - & 2.2 & 1.2 \\
\hline Briza media & 1.1 & 3.3 & - & - \\
\hline Holcus lanatus & 2.2 & 3.2 & - & - \\
\hline Plantago major & - & - & 1.1 & 2.1 \\
\hline Ranunculus repens & - & - & 1.1 & 1.1 \\
\hline Taraxacum officinale & 1.1 & - & 1.1 & - \\
\hline Trifolium montanum & - & 1.1 & 1.1 & - \\
\hline Valeriana officinalis & - & - & 1.1 & 1.1 \\
\hline Achillea millefolium & - & - & 2.2 & - \\
\hline Laserpitium prutenicum & - & - & + & - \\
\hline \multicolumn{5}{|l|}{ ChCl. Artemisietea vulgaris } \\
\hline Chaerophyllum temulum & - & - & - & 2.2 \\
\hline Melilotus officinalis & - & 1.1 & - & - \\
\hline Arctium tomentosum & - & - & + & - \\
\hline Cirsium arvense & - & - & + & - \\
\hline Medicago lupulina & + & - & - & - \\
\hline \multicolumn{5}{|c|}{ ChCl. Trifolio-Geranietea sanguinei } \\
\hline Galium verum & 1.1 & 1.1 & 2.2 & + \\
\hline \multicolumn{5}{|c|}{ ChCl. Agropyretea intermedio-repentis } \\
\hline Equisetum arvense & - & - & 1.2 & - \\
\hline \multicolumn{5}{|l|}{ ChCl. Epilobietea angustifolii } \\
\hline Fragaria vesca & 2.2 & 2.2 & - & - \\
\hline \multicolumn{5}{|l|}{ ChCl. Festuco-Brometea } \\
\hline Brachypodium pinnatum & - & 1.1 & 1.1 & - \\
\hline \multicolumn{5}{|c|}{$\mathrm{ChCl}$. Koelerio glaucae-Corynephoretea canescentis } \\
\hline Rumex acetosella & + & - & - & + \\
\hline \multicolumn{5}{|l|}{ ChCl. Stellarietea mediae } \\
\hline Aethusa cynapium & - & - & - & 1.2 \\
\hline \multicolumn{5}{|l|}{ Others } \\
\hline Lolium multiflorum & 1.1 & 1.1 & 1.1 & 1.1 \\
\hline Salvia pratensis & - & 1.1 & - & - \\
\hline Silene chlorantha & - & - & + & - \\
\hline
\end{tabular}




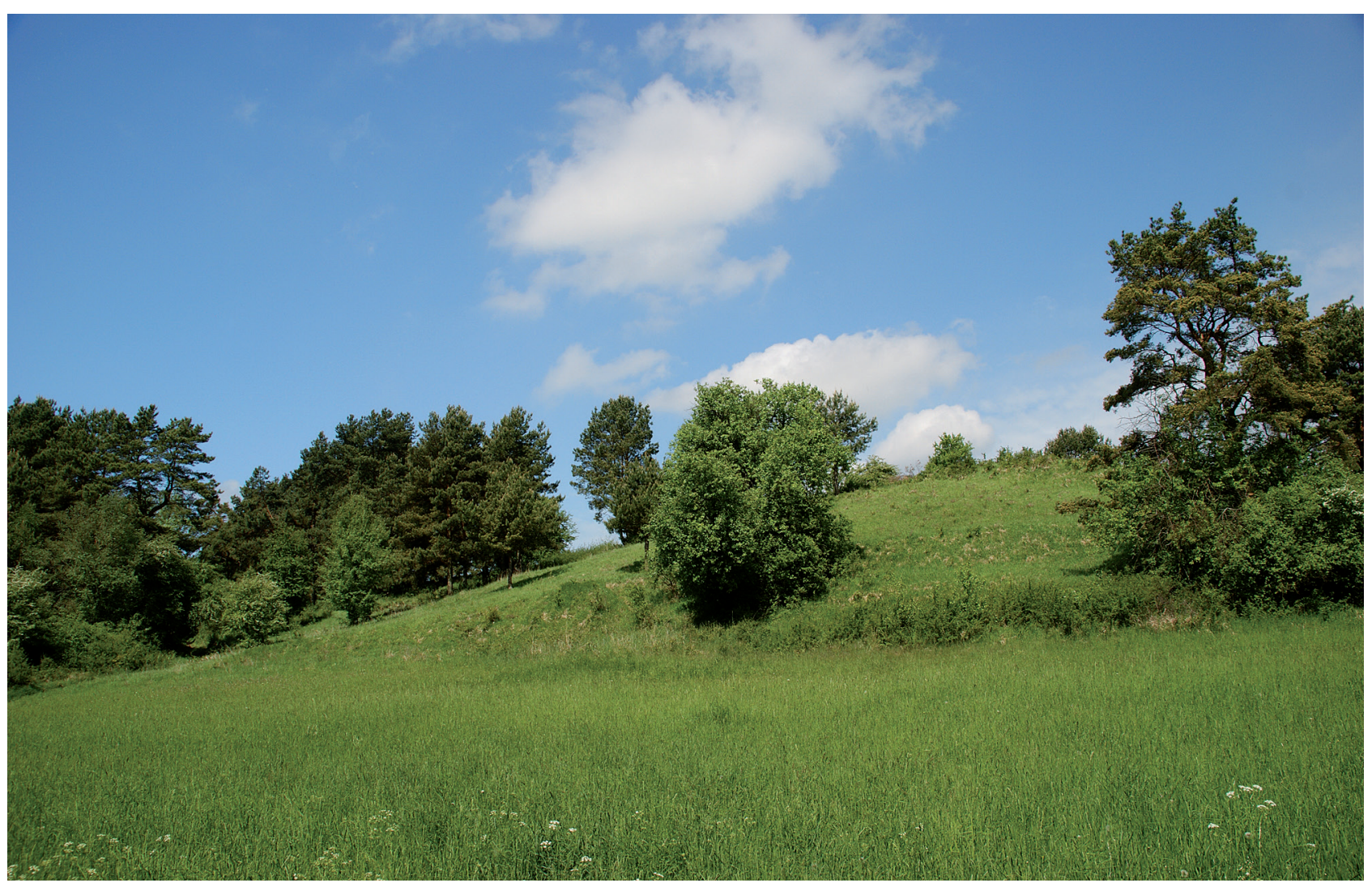

Phot. 4. Meadow from the Molinio-Arrhenatheretea class in the foreground, morain hills seen in the background (phot. M. Kagan)

Communities from the Molinio-Arrhenatheretea class are most typically semi-natural and anthropogenic communities. They frequently serve the productive functions, providing high quality value of the feed (Phot. 4). In the discussed area all such meadows are utilised. Plots documented in relevés 10, 12 and 13 are cut at least once a year. Relevé no. 16 was established in a location where horses were grazing until 2012. Fresh meadows also play an important natural role in the landscape.

On average in that relevé 19 species were recorded (from 18 to 23). The herbaceous layer was dominated by Avenula pubescens and Dactylis glomerata. Plants representing other classes were found rarely, e.g. Artemisietea vulgaris, Trifolio-Geranietea sanguinei, Agropyretea intermedio-repentis, Epilobietea angustifolii, Festuco-Brometea, Koelerio glaucae-Corynephoretea canescentis and Stellarietea mediae. Totally 34 species of vascular plants were reported in all the relevés established in patches of communities from the Molinio-Arrhenatheretea class. The herb layer cover is considerable and on average amounts to $95 \%$.

In the Moryńskie Hills we may presently observe threats for the habitats found there. A dangerous phenomenon for the xerothermic grassland is connected with a lack of extensive land use and the vicinity of arable fields. In this case biogen runoff from field poses a threat, leading to eutrophication of these habitats. Until recently extesive grazing was conducted on grassland, which had a positive impact on this habitat. Grazing on the vegetation and trampling caused microerosion, preveting encroachment of woody species. Grazing was abandoned recently and in this way surface erosion ceased. This leads to an increased accumulation of organic matter, herb vegetation cover increases in the patches, which results in changes in microclimatic conditions within xerothermic grassland. Another important threat is connected with fragmentation and isolation of plots of swards. The Moryńskie Hills are surrounded by arable fields. Such an isolation seriously hinders the spread of xerothermic species. The nearest phytocenoses of xerothermic swards are found only on slopes surrounding the Odra river valley at a distance of around a dozen $\mathrm{km}$ to the west. Frequently in the grasslands an intensive process of encroachment by taxa alien for this habitat may be observed. They are usually species of shrub communities: Prunus spinosa and Crataegus laevigata (Phot. 5). Rubus caesius is a very common species, with young Pinus sylvestris, or Pyrus communis and Robinia pseudacacia being found less frequently. In meadows and pastures from the Molinio-Arrhenatheretea class a considerable impact of the lowering of groundwater table may be observed (NATURA 2000). This problem has been evident for some time now. As a result of changes in water relations we may frequently observe the vegetation preferring more moist and more fertile habitats being elimitaed from this area, while a neg- 


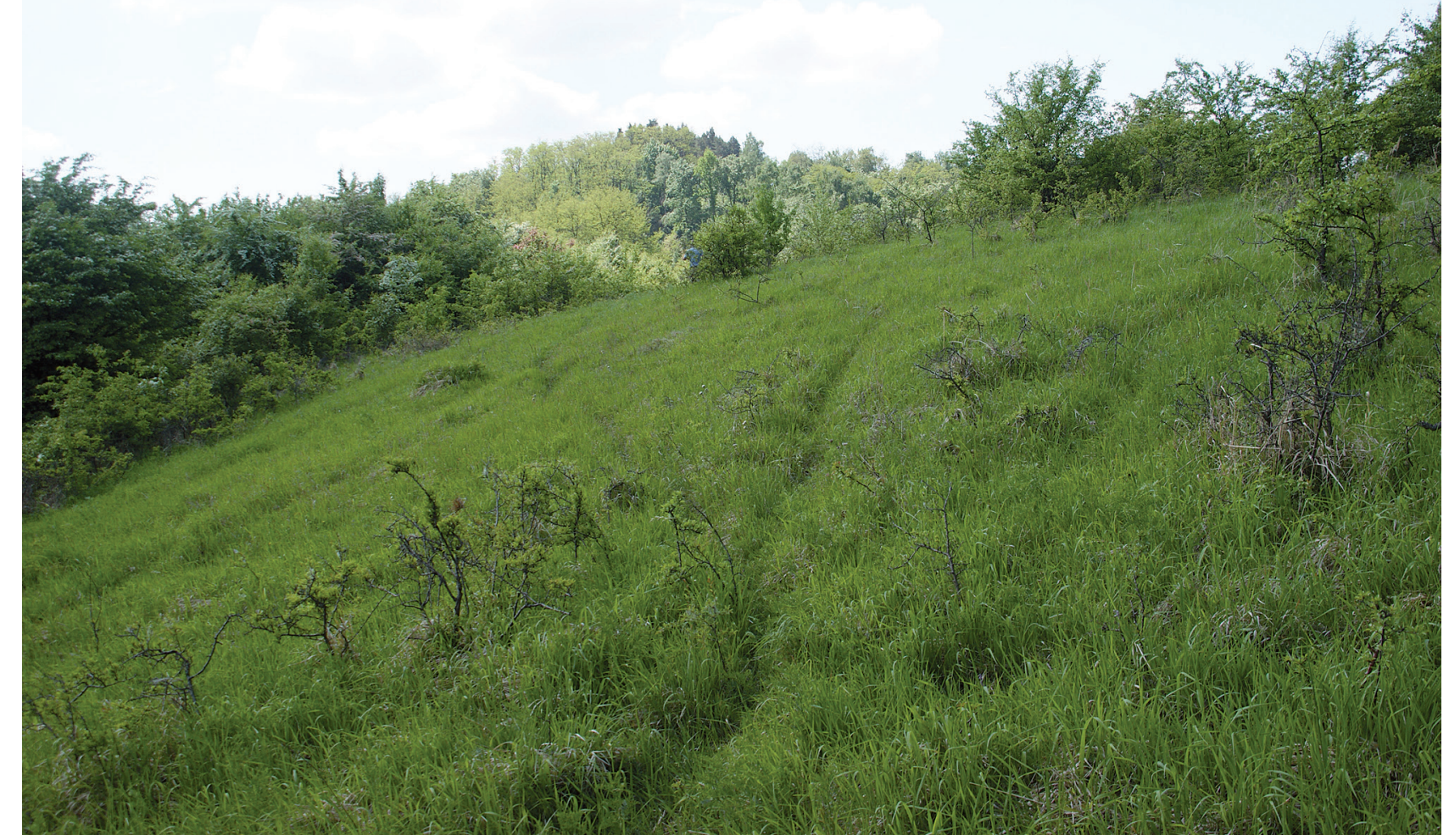

Phot. 5. Overgrown xerothermic grassland, Crataegus laevigata shrubs seen in the background (phot. M. Kagan)

ative effect is also observed on in-field, thawed-out glacial small water bodies. Many such small water bodies simly diappeared from the landscape, which was followed by the depletion of valuable refuges of fauna and flora.

Blackthorn thickets, while being dangerous for xerothermic swards, may be susceptible to various threats. Communities from the Rhamno-Prunetea class are subjected to secondary succession. A considerable share of trees in the thickets (Quercus petraea and Ulmus laevis) may lead to changes in light conditions, as trees by limiting access to light have a signiifcant influence on shrub vegetation (MATUSZKIEWICZ ET AL. 2012) and transform it into forest commnities. In the Moryńskie Hills Robinia pseudacacia is frequently found in thickets. Ripariam forests with Viola odorata growing on slopes are at risk of penetration by alien species. In the Moryńskie Hills Robinia pseudacacia is the species encroaching most frequently into riparian forest, with the largest patches with black locust found in the cental and northern parts of the study area. This species highly frequently grows on forest edges and in more strongly isolated sites. Frequently we may also observed the phenomenon of pine encroachment (pinetysation). In many places in the riparian habitats the upper tree layer is composed of Pinus sylvestris alone, which was especially evident in the southern part of the study area (relevés 19 and 21). Anoth- er very important factor affecting riparian forests is connected with the previously mentioned loweirng of the groundwater table. The deteriorating water relations do not promote fertile riparian forest sites and cause their degeneration.

\section{INDICATIONS FOR MANAGEMENT}

The best method to preserve xerothermic swards is to return to extensive grazing management. Grazing is the simplest and cheapest method to maintain and protect grassland. The intensity of grazing determines what type of termophilous grassland will be formed, as on very dry habitats at low intensity of management phytocenoses of Stipa sp. are formed. Swards should be cut only once a year, since the later regrowth of green material is strongly limited by the unfavourable water conditions (they are low-producing meadows). Hay from xerothermic grassland is very rarely used due to the problems with its harvest (it is found typically on steep slopes) and the very small amount of produced forage. However, such hay has specific feeding value thanks to the considrable amounts of herbs (WYSOCKI \& SIKORSKI 2009).

In the case when woody species appear in grassland, grazing alone is not sufficient. In such a situation all woody plants need to be cut down so that they may not produce sprouts in the same vegetation season. Only after such a procedure extensive graz- 
ing may be introduced, which will considerably limit growth and spread of the shrub vegetation.

In order to improve the natural value of riparian carr forests with sweet violet Viola odorata growing on slopes, alien species have to be eliminated gradually, mainly Robinia pseudacacia found in large numbers in the study area. It is highly advisable to transform pine stands found in the riparian forest site. It may be difficult to prevent the lowering of groundwater levels, which has a considerable effect on the occurrence of the specific natural habitats.

\section{CONCLUDING REMARKS}

The Moryńskie Hills are characterised by the occurrence of various conditions, both geomorphological and habitat. Thanks to such a diversity, this area is a mosaic of plant communities. In places extremely arid grasslands and fertile riparian forests grow in the nearest vicinity. On steep slopes we find most frequently xerothermic swards and riparian forests with Viola odorata. Swamp vegetation grows in numerous post-glacial depressions, while in levelled areas there are meadows and pastures mainly from the Molinio-Arrhenatheretea class.

In the study area there are two types of potential natural vegetation (MATUSZKIEWICZ 2008 a): fertile lowland beech forest Galio odorati-Fagetum and steppe xerothermic grassland Festucetalia valesiacae.

Actual vegetation is first of all the result of human activity. Mainly forested areas were changed and tranformed into farmland.

In the study area a total of 186 taxa of vascular plants were found. Species recorded in that area belong to 47 families, of which the family Poaceae is the most numerous with 29 species. Flora of the Hills to a considerable degree is natural in character. Non-synathropic spontaneophytes and apophytes constitute $92 \%$ flora. The most numerous group of life forms comprises hemicryptophytes $(61 \%)$, with numerous representatives of therophytes (12.9\%) and geophytes $(10.2 \%)$, while the other groups account for $15 \%$ flora in the study area.

A large group of species found in the Hills comprises taxa covered by various forms of law protection. As many as four species are covered by strict protection (Anthericum liliago, Campanula sibirica, Centaurium erythraea and Stipa capillata), with three species from this group requiring active protection. The partial protection status has been awarded to four species (Helichrysum arenarium, Primula veris, Viburnum opulus and Galium odoratum). Anthericum liliago, is the only species from that area registered in the Polish red book (species threatened with extinction). From among rare and threatened species in the Western Pomerania (ŻUKowsKi \& JACKOWIAK 1995) eight taxa were recorded, i.e. six endagered species, as well as one species with deficient data and unspecific risk, and one rare species. Among all the plants specified in Attachment 2 to Directive no. 92/43/EEC (DYReKTYWA... 1992) in the study area five taxa and 11 species classfied as species of ancient woodlands. Plant communities of the Moryńskie Hills belong to nine syntaxonomic classes. The most abundant, i.e. comprising 46 species, was Molinio-Arrhenatheretea class, followed by Artemisietea vulgaris (28 species), with classes Festuco-Brometea and Querco-Fagetea comprising 17 taxa each. A relatively numerous gruop was composed of other species, beloging to none of the classes, i.e. the socalled accompanying species.

Most plant communities in the study area are non-forest in character. A large area is covered by xerothermic grassland from the Festuco-Brometea class, with a slightly smaller area being covered by meadows and pastures from the Molinio-Arrhenatheretea class, as well as shrub communities from the Rhamno-Prunetea class. Forest vegetation is represented by riparian forests (Querco-Fagetea class) covering mainly the southern part of the Hills, while in the central part of the study area found only in the immediate vicinity of Lake Górka. The northern part is overgrown mainly by shrubs (Rhamno-Prunetea class) and xerothermic grassland (Festuco-Brometea class). Meadows and pastures (Molinio-Arrhenatheretea class) grow mostly on the central part of the Hills and are found mainly on flat land.

The greatest threat to xerothermic swards in the discussed area is connected with the decision to cease extensive grazing. This leads as a consequence to overgowing of such plots, which results in a slow change in the habitat conditions. Such grasslands are encroached by vegetation from more fertile communities, and organic matter deposition is enhanced. Frequently the first shrub plants, mainly Prunus spinosa and Crataegus laevigata, appear in such locations.

A relatively large number of riparian forest phytocenoses underwent various forms of degeneration: pine ecroachment and encroachment by neophytes, due to the encroachment of aline woody species, mainly Robinia pseudacacia. Another difficult to eliminate, negative phenomenon is connected with the lowering of groundwater levels.

The most important protection measure which may prove applicable in the Moryńskie Hills is to re-introduce extensive grazing. Such an action would lead to the preservation of existing xerothermic grasslands and reduction of the spread of shrub communities.

\section{REFERENCES}

Borówka R., Friedrich S., Heese T., Jasnowska J., KoChanowska R., Opęchowski M., Stanecka E., Zyska W. (2004): Przyroda Pomorza Zachodniego. Oficyna In Plus, Szczecin. 
Braun-Blanquet J. (1964): Pflanzensoziologie, Grundlage der Vegetationskunde. Springer, Wien-New York.

Celiński F. (1953 a): Czynniki glebowe a roślinność kserotermiczna Wielkopolskiego Parku Narodowego pod Poznaniem. Poznańskie Towarzystwo Przyjaciół Nauk. Prace Monograficzne nad Przyrodą Wielkopolskiego Parku Narodowego pod Poznaniem 2, 8 .

Celiński F. (1953 b): Pontyjskie zbocza koło Grędźca nad jeziorem Miedwie. Chrońmy Przyrodę Ojczystą 3(9): 25-32.

Celiński F. (1954): Flora pontyjska w Mielniku nad Bugiem. Chrońmy Przyrodę Ojczystą 6(10): 21-27.

Celiński F. (1957): Rezerwat leśno-stepowy w Bielinku nad Odrą. Ochrona Przyrody 24: 221-271.

Celiński F., FILIPEK M. (1958): Flora i zespoły roślinne leśno-stepowego rezerwatu w Bielinku nad Odrą. Badania Fizjograficzne nad Polską Zachodnią seria B, 4: 221-271.

Ceynowa M. (1968): Zbiorowiska roślinności kserotermicznej nad dolną Wisłą. Studia Societatis Scientiarum, Toruń, Sectio D, 8(4).

Czeczotowa H. (1948): O rezerwacie leśno-stepowym w Bielinku nad Odrą. Chrońmy Przyrodę Ojczystą 4(5-6): 5-11.

DyreKTYWA Rady 92/43/EWG z dnia 21 maja 1992 r. W sprawie ochrony siedlisk przyrodniczych oraz dzikiej fauny i flory. (1992). Dz.U. L 206 z 22.7.1992 (str. 7, Załącznik II).

Dzwonko Z. (2007): Przewodnik do badań fitosocjologicznych. Vademecum Geobotanicum, Poznań, Kraków.

FIJAŁKOWSKI D. (1957): Zbiorowiska kserotermiczne projektowanego rezerwatu stepowego koło Czumowa nad Bugiem. Annales Universitatis Mariae Curie-Skłodowska, Sectio C, 10: 311-319.

FILIPEK M. (1974): Murawy kserotermiczne regionu dolnej Odry i Warty. Prace Komisji Biologicznej, Poznańskie Towarzystwo Przyjaciół Nauk 38.

GOOGLE MAP Google Earth w skali 1:5000.

Jermaczek A., Pawlaczyk P., Rybaczyk E. (2005): Murawy kserotermiczne nad Odrą, Wartą i Notecią. Przewodnik turystyczno-przyrodniczy, Wydawnictwo Klubu Przyrodników, Świebodzin.

KaźmierczaKowa R., ZarzycKi K. (eds) (2001): Polska czerwona księga roślin. Paprotniki i rośliny kwiatowe. Instytut Botaniki im. W. Szafera PAN, Kraków.

KondRACKI J. (2002): Geografia regionalna Polski. Wyd. Nauk. PWN, Warszawa.

LiRo A. (1998): Strategia wdrażania krajowej sieci ekologicznej ECONET - Polska. Fundacja IUCN Poland, Warszawa.

MatuszKiewicz J.M. (1993): Krajobrazy roślinne i regiony geobotaniczne Polski. Prace Geograficzne IGiPZ PAN 158
MatuszKiewicz J.M. (2008): Potential natural vegetation of Poland (Potencjalna roślinność naturalna Polski). Instytut Geografii i Przestrzennego Zagospodarowanie PAN, Warszawa.

MAtuszKiewicz W. (2008): Przewodnik do oznaczania zbiorowisk roślinnych Polski. Wyd. Nauk. PWN, Warszawa.

Matuszkiewicz W., Sikorski P., Szwed W., Danielewicz W., Kiciński P., WierzbA M. (2012): Przegląd zespołów leśnych występujących w Polsce. In: W. Matuszkiewicz, P. Sikorski, W. Szwed, M. Wierzba (eds). Lasy i zarośla. Zbiorowiska roślinne Polski. Ilustrowany przewodnik. Wyd. Nauk. PWN, Warszawa.

MieczyŃsKi T. (1947): Gleby i wytwórczość Pomorza Zachodniego. Wydawnictwo Instytutu Bałtyckiego, Gdańsk-Bydgoszcz-Szczecin.

Mirek Z., PięKoś-Mirkowa H., Zając M., Zając A. (2002): Flowering plants and pteridophytes of Poland. A checklist. Vol. 1. Biodiversity of Poland. - Krytyczna lista roślin naczyniowych Polski. T. 1. Różnorodność biologiczna Polski. W. Szafer Institute of Botany, Polish Academy of Sciences, Kraków.

Natura 2000, Standardowy Formularz Danych dla obszarów specjalnej ochrony (OSO) dla obszarów spełniających kryteria obszarów o znaczeniu wspólnotowym (OZW) i dla pecjalnych obszarów ochrony (SOO); (natura2000.gdos.gov.pl/datafiles/download/PLH320055/sdf; 22.03.2013 r.).

Perzanowska J., Kujawa-Pawlaczyk J. (2004): Murawy kserotermiczne (Festuco-Brometea). In: J. Herbich (ed.). Murawy, łąki, ziołorośla, wrzosowiska, zarośla. Poradniki ochrony siedlisk i gatunków Natura 2000 - poradnik metodyczny. T. 3. Ministerstwo Środowiska, Warszawa: 117-139.

Peterken G. F. (1974): A method for assessing woodland flora for conservation using indicator species. Biological Conservation. 6: 239-245.

RAUNKIAER C. (1905): Types biologiques pour la géographie botanique. Oversigt over Det Kongelige Danske Videnskabernes Selskabs Forhandlinger: 347-438.

RĄKOwski G. (2002): Parki krajobrazowe w Polsce. Instytut Ochrony Środowiska, Warszawa.

RozPorzĄDzEnIE Ministra Środowiska z dnia 5 stycznia 2012 r. w sprawie ochrony gatunkowej roślin. (2012). Dz.U. z dnia 20 stycznia 2012 r., poz. 81.

SŁAWIŃSKI W. (1952): Zespoły kserotermiczne okolic Kazimierza nad Wisłą. Annales Uniwersitatis Mariae Curie-Skłodowska, Sectio E, 6: 47-60.

Thellung A. (1915): Pflanzenwanderungen unter dem Einfluss des Menschen. Botanische Jahresbücher für Systematik, Pflanzengeschichte und Pflanzengeographie 53(3-5), 116: 37-66.

Wysocki C., Sikorski P. (2009): Fitosocjologia stosowana w ochronie i kształtowaniu krajobrazu. Wy- 
dawnictwo Szkoła Główna Gospodarstwa Wiejskiego, Warszawa.

ŻuKowsKi W., JAcKowiak B. (1995): Lista roślin naczyniowych ginących i zagrożonych na Pomorzu Zachodnim i w Wielkopolsce. In: W. Żukowski,
B. Jackowiak (eds). Ginące i zagrożone rośliny naczyniowe Pomorza Zachodniego i Wielkopolski. Prace Zakładu Taksonomii Roślin UAM w Poznaniu 3. Bogucki Wydawnictwo Naukowe, Poznań. 


\section{ANNEX}

Vascular plants of the Moryńskie Hills occuring in the transects and plots of phytosociological relevés and family, life forms of Raunkiaer (GRRA), geographic-historical group of species (GRHG) and phytosociological class (ChCl)

\begin{tabular}{|c|c|c|c|c|c|}
\hline No. & Species & Family & GRRA & GRHG & $\mathrm{ChCl}$ \\
\hline 1 & Acer campestre & Aceraceae & M & Ap & R-P \\
\hline 2 & Acer pseudoplatanus & Aceraceae & M & Ap & Q-F \\
\hline 3 & Achillea millefolium & Asteraceae & $\mathrm{H}$ & Ap & M-A \\
\hline 4 & Acinos arvensis & Lamiaceae & $\mathrm{TH}$ & Ap & F-B \\
\hline 5 & Aegopodium podagraria & Apiaceae & $\mathrm{H}$ & Ap & AV \\
\hline 6 & Aethusa cynapium & Apiaceae & $\mathrm{T}$ & $\mathrm{Ap} / \mathrm{Ar}$ & SM \\
\hline 7 & Agrimonia eupatoria & Rosaceae & $\mathrm{H}$ & Ap & $\mathrm{T}-\mathrm{G}$ \\
\hline 8 & Ajuga genevensis & Lamiaceae & $\mathrm{H}$ & $\mathrm{Sn}$ & F-B \\
\hline 9 & Ajuga reptans & Lamiaceae & $\mathrm{H}$ & $\mathrm{Sn}$ & V-P \\
\hline 10 & Alliaria petiolata & Brassicaceae & $\mathrm{H}$ & Ap & AV \\
\hline 11 & Allium vineale & Liliaceae & G & Ap & - \\
\hline 12 & Alnus glutinosa & Betulaceae & M & Ap & Q-F \\
\hline 13 & Alopecurus pratensis & Poaceae & $\mathrm{H}$ & Ap & M-A \\
\hline 14 & Anchusa officinalis & Boraginaceae & $\mathrm{H}$ & Ap & AV \\
\hline 15 & Anthericum liliago & Liliaceae & G & $\mathrm{Sn}$ & F-B \\
\hline 16 & Anthoxanthum odoratum & Poaceae & $\mathrm{H}$ & Ap & $\mathrm{K}-\mathrm{C}$ \\
\hline 17 & Anthyllis vulneraria & Fabaceae & $\mathrm{H}$ & Ap & F-B \\
\hline 18 & Arctium tomentosum & Asteraceae & $\mathrm{H}$ & Ap & AV \\
\hline 19 & Armeria elongata & Plumbaginaceae & $\mathrm{H}$ & Ap & $\mathrm{K}-\mathrm{C}$ \\
\hline 20 & Arrhenatherum elatius & Poaceae & $\mathrm{H}$ & Ap & M-A \\
\hline 21 & Artemisia campestris & Asteraceae & $\mathrm{Ch}$ & Ap & F-B \\
\hline 22 & Asparagus officinalis & Liliaceae & G & Ap & F-B \\
\hline 23 & Astragalus glycyphyllos & Fabaceae & $\mathrm{H}$ & Ap & $\mathrm{T}-\mathrm{G}$ \\
\hline 24 & Avenula pubescens & Poaceae & $\mathrm{H}$ & Ap & M-A \\
\hline 25 & Berberis vulgaris & Berberidaceae & $\mathrm{N}$ & $\mathrm{Sn}$ & R-P \\
\hline 26 & Berteroa incana & Brassicaceae & HT & Ap & AV \\
\hline 27 & Betonica officinalis & Lamiaceae & $\mathrm{H}$ & $\mathrm{Sn}$ & M-A \\
\hline 28 & Betula pendula & Betulaceae & M & Ap & EA \\
\hline 29 & Bidens tripartita & Asteraceae & $\mathrm{T}$ & Ap & BT \\
\hline 30 & Brachypodium pinnatum & Poaceae & $\mathrm{H}$ & Sn & F-B \\
\hline 31 & Brachypodium sylvaticum & Poaceae & $\mathrm{H}$ & $\mathrm{Sn}$ & $\mathrm{Q}-\mathrm{F}$ \\
\hline 32 & Briza media & Poaceae & $\mathrm{H}$ & Sn & M-A \\
\hline 33 & Calamagrostis arundinacea & Poaceae & $\mathrm{H}$ & $\mathrm{Sn}$ & B-A \\
\hline 34 & Calamagrostis epigejos & Poaceae & G & Ap & EA \\
\hline 35 & Campanula glomerata & Campanulaceae & $\mathrm{H}$ & Ap & F-B \\
\hline 36 & Campanula persicifolia & Campanulaceae & $\mathrm{H}$ & $\mathrm{Sn}$ & Q-F \\
\hline 37 & Campanula rapunculoides & Campanulaceae & $\mathrm{H}$ & Ap & $\mathrm{T}-\mathrm{G}$ \\
\hline 38 & Campanula sibirica & Campanulaceae & $\mathrm{H}$ & $\mathrm{Sn}$ & F-B \\
\hline 39 & Campanula trachelium & Campanulaceae & $\mathrm{H}$ & Sn & Q-F \\
\hline 40 & Carex acutiformis & Cyperaceae & GHy & Sn & $\mathrm{P}$ \\
\hline
\end{tabular}




\begin{tabular}{|c|c|c|c|c|c|}
\hline No. & Species & Family & GRRA & GRHG & $\mathrm{ChCl}$ \\
\hline 41 & Carex fusca & Cyperaceae & G & $\mathrm{Sn}$ & $\mathrm{P}$ \\
\hline 42 & Carex gracilis & Cyperaceae & GHy & $\mathrm{Sn}$ & $\mathrm{P}$ \\
\hline 43 & Carex leporina & Cyperaceae & $\mathrm{H}$ & Ap & - \\
\hline 44 & Carlina vulgaris & Asteraceae & HT & Ap & F-B \\
\hline 45 & Carpinus betulus & Corylaceae & M & Ap & Q-F \\
\hline 46 & Centaurea jacea & Asteraceae & $\mathrm{H}$ & Ap & M-A \\
\hline 47 & Centaurea scabiosa & Asteraceae & $\mathrm{H}$ & Ap & F-B \\
\hline 48 & Centaurea stoebe & Asteraceae & $\mathrm{H}$ & Ap & - \\
\hline 49 & Centaurium erythraea & Gentianaceae & $\mathrm{T}$ & Ap & EA \\
\hline 50 & Chaerophyllum temulum & Apiaceae & TH & Ap & $\mathrm{AV}$ \\
\hline 51 & Chrysanthemum segetum & Asteraceae & $\mathrm{T}$ & $\mathrm{Ar}$ & SM \\
\hline 52 & Cirsium arvense & Asteraceae & G & Ap & $\mathrm{AV}$ \\
\hline 53 & Cirsium oleraceum & Asteraceae & $\mathrm{H}$ & Ap & M-A \\
\hline 54 & Consolida regalis & Ranunculaceae & $\mathrm{T}$ & $\mathrm{Ar}$ & SM \\
\hline 55 & Conyza canadensis & Asteraceae & $\mathrm{TH}$ & $\mathrm{Kn}$ & SM \\
\hline 56 & Coronilla varia & Fabaceae & $\mathrm{H}$ & Ap & T-G \\
\hline 57 & Corynephorus canescens & Poaceae & $\mathrm{H}$ & Ap & $\mathrm{K}-\mathrm{C}$ \\
\hline 58 & Crataegus laevigata & Rosaceae & $\mathrm{NM}$ & Ap & R-P \\
\hline 59 & Cucubalus baccifer & Caryophyllaceae & $\mathrm{H}$ & $\mathrm{Sn}$ & $\mathrm{AV}$ \\
\hline 60 & Cynoglossum officinale & Boraginaceae & $\mathrm{H}$ & Ap & $\mathrm{AV}$ \\
\hline 61 & Cynosurus cristatus & Poaceae & $\mathrm{H}$ & $\mathrm{Sn}$ & M-A \\
\hline 68 & Dactylis glomerata & Poaceae & $\mathrm{H}$ & Ap & M-A \\
\hline 63 & Deschampsia caespitosa & Poaceae & $\mathrm{H}$ & Ap & M-A \\
\hline 64 & Deschampsia flexuosa & Poaceae & $\mathrm{H}$ & $\mathrm{Sn}$ & M-A \\
\hline 65 & Dianthus carthusianorum & Caryophyllaceae & $\mathrm{C}$ & Ap & M-A \\
\hline 66 & Dryopteris filix-mas & Aspidiaceae & $\mathrm{H}$ & Ap & Q-F \\
\hline 67 & Echium vulgare & Boraginaceae & $\mathrm{H}$ & Ap & AV \\
\hline 68 & Elymus repens & Poaceae & G & Ap & M-A \\
\hline 69 & Epilobium hirsutum & Onagraceae & $\mathrm{H}$ & Ap & $\mathrm{AV}$ \\
\hline 70 & Equisetum arvense & Equisetaceae & G & Ap & AI-R \\
\hline 71 & Erigeron annuus & Asteraceae & $\mathrm{TH}$ & $\mathrm{Kn}$ & - \\
\hline 72 & Euphorbia dulcis & Euphorbiaceae & $\mathrm{GH}$ & $\mathrm{Kn}$ & Q-F \\
\hline 73 & Euphorbia esula & Euphorbiaceae & $\mathrm{H}$ & Ap & - \\
\hline 74 & Falcaria vulgaris & Apiaceae & $\mathrm{H}$ & Ap & AI-R \\
\hline 75 & Festuca arundinacea & Poaceae & $\mathrm{H}$ & Ap & M-A \\
\hline 76 & Festuca duriuscula & Poaceae & $\mathrm{H}$ & Ap & - \\
\hline 77 & Festuca pratensis & Poaceae & $\mathrm{H}$ & Ap & M-A \\
\hline 78 & Festuca rubra & Poaceae & $\mathrm{H}$ & Ap & M-A \\
\hline 79 & Filipendula ulmaria & Rosaceae & $\mathrm{H}$ & Ap & M-A \\
\hline 80 & Filipendula vulgaris & Rosaceae & $\mathrm{H}$ & Ap & F-B \\
\hline 81 & Fragaria vesca & Rosaceae & $\mathrm{H}$ & Ap & EA \\
\hline 82 & Fraxinus excelsior & Oleaceae & M & Ap & Q-F \\
\hline 83 & Galium aparine & Rubiaceae & $\mathrm{T}$ & Ap & $\mathrm{AV}$ \\
\hline
\end{tabular}




\begin{tabular}{|c|c|c|c|c|c|}
\hline No. & Species & Family & GRRA & GRHG & $\mathrm{ChCl}$ \\
\hline 84 & Galium odoratum & Rubiaceae & $\mathrm{H}$ & $\mathrm{Sn}$ & Q-F \\
\hline 85 & Galium mollugo & Rubiaceae & $\mathrm{H}$ & Ap & M-A \\
\hline 86 & Galium sylvaticum & Rubiaceae & G & $\mathrm{Sn}$ & Q-F \\
\hline 87 & Galium verum & Rubiaceae & $\mathrm{H}$ & Ap & T-G \\
\hline 88 & Geranium pratense & Geraniaceae & $\mathrm{H}$ & Ap & M-A \\
\hline 89 & Geranium robertianum & Geraniaceae & TH & Ap & $\mathrm{AV}$ \\
\hline 90 & Geum rivale & Rosaceae & $\mathrm{H}$ & Ap & M-A \\
\hline 91 & Geum urbanum & Rosaceae & $\mathrm{H}$ & Ap & AV \\
\hline 92 & Glechoma hederacea & Lamiaceae & $\mathrm{GH}$ & Ap & AV \\
\hline 93 & Glyceria plicata & Poaceae & Hy & Ap & $\mathrm{P}$ \\
\hline 94 & Helichrysum arenarium & Asteraceae & $\mathrm{H}$ & Ap & $\mathrm{K}-\mathrm{C}$ \\
\hline 95 & Holcus lanatus & Poaceae & $\mathrm{H}$ & Ap & M-A \\
\hline 96 & Hypericum perforatum & Hypericaceae & $\mathrm{H}$ & Ap & $\mathrm{AV}$ \\
\hline 97 & Impatiens noli-tangere & Balsaminaceae & $\mathrm{T}$ & $\mathrm{Sn}$ & Q-F \\
\hline 98 & Iris pseudacorus & Iridaceae & HG & $\mathrm{Sn}$ & $\mathrm{P}$ \\
\hline 99 & Juncus articulatus & Juncaceae & $\mathrm{H}$ & Ap & $\mathrm{S}-\mathrm{CN}$ \\
\hline 100 & Knautia arvensis & Dipsacaceae & $\mathrm{H}$ & Ap & $\mathrm{M}-\mathrm{A}$ \\
\hline 101 & Koeleria glauca & Poaceae & $\mathrm{H}$ & $\mathrm{Sn}$ & $\mathrm{K}-\mathrm{C}$ \\
\hline 102 & Lamium maculatum & Lamiaceae & $\mathrm{H}$ & $\mathrm{Sn}$ & $\mathrm{AV}$ \\
\hline 103 & Lapsana communis & Asteraceae & HT & Ap & SM \\
\hline 104 & Laserpitium prutenicum & Apiaceae & $\mathrm{H}$ & $\mathrm{Sn}$ & M-A \\
\hline 105 & Leontodon hispidus & Asteraceae & $\mathrm{H}$ & Ap & B-A \\
\hline 106 & Leucanthemum vulgare & Asteraceae & $\mathrm{H}$ & Ap & M-A \\
\hline 107 & Linaria vulgaris & Scrophulariaceae & G & Ap & $\mathrm{AV}$ \\
\hline 108 & Linum catharticum & Linaceae & $\mathrm{T}$ & $\mathrm{Sn}$ & M-A \\
\hline 109 & Lolium multiflorum & Poaceae & HT & $\mathrm{Kn}$ & - \\
\hline 110 & Lotus corniculatus & Fabaceae & $\mathrm{H}$ & Ap & $\mathrm{M}-\mathrm{A}$ \\
\hline 111 & Lychnis flos-cuculi & Caryophyllaceae & $\mathrm{H}$ & $\mathrm{Sn}$ & M-A \\
\hline 112 & Lysimachia vulgaris & Primulaceae & $\mathrm{H}$ & Ap & M-A \\
\hline 113 & Medicago lupulina & Fabaceae & TH & Ap & $\mathrm{AV}$ \\
\hline 114 & Medicago sativa & Fabaceae & $\mathrm{H}$ & $\mathrm{Ee}$ & $\mathrm{AV}$ \\
\hline 115 & Melampyrum arvense & Scrophulariaceae & Tpp & $\mathrm{Sn}$ & F-B \\
\hline 116 & Melilotus albus & Fabaceae & $\mathrm{T}$ & Ap & AV \\
\hline 117 & Melilotus officinalis & Fabaceae & $\mathrm{T}$ & Ap & $\mathrm{AV}$ \\
\hline 118 & Moehringia trinervia & Caryophyllaceae & TH & Ap & $\mathrm{AV}$ \\
\hline 119 & Myosotis arvensis & Boraginaceae & $\mathrm{TH}$ & $\mathrm{Ar}$ & SM \\
\hline 120 & Odontites verna & Scrophulariaceae & Tpp & $\mathrm{Ar}$ & SM \\
\hline 121 & Ononis spinosa & Fabaceae & $\mathrm{HN}$ & Ap & - \\
\hline 122 & Origanum vulgare & Lamiaceae & $\mathrm{HC}$ & Ap & T-G \\
\hline 123 & Orobanche ramosa & Orobanchaceae & G & $\mathrm{Kn}$ & SM \\
\hline 124 & Petrorhagia prolifera & Caryophyllaceae & $\mathrm{T}$ & Ap & - \\
\hline 125 & Peucedanum palustre & Apiaceae & $\mathrm{H}$ & $\mathrm{Sn}$ & $\mathrm{P}$ \\
\hline 126 & Phleum phleoides & Poaceae & $\mathrm{H}$ & $\mathrm{Sn}$ & F-B \\
\hline
\end{tabular}




\begin{tabular}{|c|c|c|c|c|c|}
\hline No. & Species & Family & GRRA & GRHG & $\mathrm{ChCl}$ \\
\hline 127 & Phleum pratense & Poaceae & $\mathrm{H}$ & Ap & M-A \\
\hline 128 & Phragmites australis & Poaceae & GHy & Ap & $\mathrm{P}$ \\
\hline 129 & Pinus sylvestris & Pinaceae & M & Ap & V-P \\
\hline 130 & Plantago lanceolata & Plantaginaceae & $\mathrm{H}$ & Ap & M-A \\
\hline 131 & Plantago major & Plantaginaceae & $\mathrm{H}$ & Ap & M-A \\
\hline 132 & Poa nemoralis & Poaceae & $\mathrm{H}$ & Ap & Q-F \\
\hline 133 & Poa pratensis & Poaceae & $\mathrm{H}$ & Ap & M-A \\
\hline 134 & Polygala vulgaris & Polygalaceae & $\mathrm{H}$ & $\mathrm{Sn}$ & $\mathrm{N}-\mathrm{C}$ \\
\hline 135 & Potentilla argentea & Rosaceae & $\mathrm{H}$ & Ap & $\mathrm{AV}$ \\
\hline 136 & Potentilla recta & Rosaceae & $\mathrm{H}$ & Ap & - \\
\hline 137 & Primula veris & Primulaceae & $\mathrm{H}$ & Ap & Q-F \\
\hline 138 & Prunella vulgaris & Lamiaceae & $\mathrm{H}$ & Ap & M-A \\
\hline 139 & Prunus spinosa & Rosaceae & $\mathrm{N}$ & Ap & R-P \\
\hline 140 & Pyrus communis & Rosaceae & M & Ap & - \\
\hline 141 & Quercus petraea & Fagaceae & M & $\mathrm{Sn}$ & Q-F \\
\hline 142 & Ranunculus acris & Ranunculaceae & $\mathrm{H}$ & Ap & M-A \\
\hline 143 & Ranunculus repens & Ranunculaceae & $\mathrm{H}$ & Ap & M-A \\
\hline 144 & Rhamnus cathartica & Rhamnaceae & $\mathrm{N}$ & Ap & R-P \\
\hline 145 & Robinia pseudacacia & Fabaceae & M & $\mathrm{Kn}$ & - \\
\hline 146 & Rosa canina & Rosaceae & $\mathrm{N}$ & Ap & R-P \\
\hline 147 & Rubus caesius & Rosaceae & $\mathrm{N}$ & Ap & $\mathrm{AV}$ \\
\hline 148 & Rumex acetosella & Polygonaceae & $\mathrm{GH}$ & Ap & $\mathrm{K}-\mathrm{C}$ \\
\hline 149 & Salix alba & Salicaceae & M & Ap & SP \\
\hline 150 & Salix aurita & Salicaceae & $\mathrm{N}$ & Ap & $\mathrm{AG}$ \\
\hline 151 & Salvia pratensis & Lamiaceae & $\mathrm{H}$ & Ap & - \\
\hline 152 & Sambucus nigra & Caprifoliaceae & $\mathrm{N}$ & Ap & EA \\
\hline 153 & Sedum acre & Crassulaceae & $\mathrm{C}$ & Ap & $\mathrm{K}-\mathrm{C}$ \\
\hline 154 & Sedum maximum & Crassulaceae & $\mathrm{HG}$ & Ap & - \\
\hline 155 & Silene chlorantha & Caryophyllaceae & $\mathrm{H}$ & $\mathrm{Sn}$ & - \\
\hline 156 & Silene otites & Caryophyllaceae & $\mathrm{H}$ & Ap & AT \\
\hline 157 & Silene vulgaris & Caryophyllaceae & $\mathrm{HC}$ & Ap & SM \\
\hline 158 & Solidago canadensis & Asteraceae & $\mathrm{HG}$ & $\mathrm{Kn}$ & AV \\
\hline 159 & Sorbus aucuparia & Rosaceae & NM & Ap & $\mathrm{T}-\mathrm{G}$ \\
\hline 160 & Stachys palustris & Lamiaceae & $\mathrm{G}$ & Ap & M-A \\
\hline 161 & Stachys recta & Lamiaceae & $\mathrm{H}$ & $\mathrm{Sn}$ & F-B \\
\hline 162 & Stellaria media & Caryophyllaceae & $\mathrm{T}$ & Ap & SM \\
\hline 163 & Stellaria nemorum & Caryophyllaceae & $\mathrm{H}$ & $\mathrm{Sn}$ & Q-F \\
\hline 164 & Stipa capillata & Poaceae & $\mathrm{H}$ & $\mathrm{Sn}$ & F-B \\
\hline 165 & Symphytum officinale & Boraginaceae & HG & Ap & M-A \\
\hline 166 & Taraxacum officinale & Asteraceae & $\mathrm{H}$ & Ap & M-A \\
\hline 167 & Thalictrum minus & Ranunculaceae & $\mathrm{H}$ & $\mathrm{Sn}$ & $\mathrm{T}-\mathrm{G}$ \\
\hline 168 & Thalictrum simplex & Ranunculaceae & $\mathrm{H}$ & $\mathrm{Sn}$ & F-B \\
\hline 169 & Thymus pulegioides & Lamiaceae & $\mathrm{C}$ & Ap & AT \\
\hline
\end{tabular}




\begin{tabular}{|c|c|c|c|c|c|}
\hline No. & Species & Family & GRRA & GRHG & $\mathrm{ChCl}$ \\
\hline 170 & Tragopogon pratensis & Asteraceae & $\mathrm{H}$ & Ap & M-A \\
\hline 171 & Trifolium arvense & Fabaceae & $\mathrm{T}$ & Ap & $\mathrm{K}-\mathrm{C}$ \\
\hline 172 & Trifolium medium & Fabaceae & $\mathrm{H}$ & Ap & $\mathrm{T}-\mathrm{G}$ \\
\hline 173 & Trifolium montanum & Fabaceae & $\mathrm{H}$ & $\mathrm{Sn}$ & M-A \\
\hline 174 & Trifolium pratense & Fabaceae & $\mathrm{H}$ & Ap & M-A \\
\hline 175 & Trifolium repens & Fabaceae & $\mathrm{CH}$ & Ap & M-A \\
\hline 176 & Tussilago farfara & Asteraceae & G & Ap & AI-R \\
\hline 177 & Ulmus laevis & Ulmaceae & M & Ap & Q-F \\
\hline 178 & Urtica dioica & Urticaceae & $\mathrm{H}$ & Ap & AV \\
\hline 179 & Valeriana officinalis & Valerianaceae & $\mathrm{H}$ & Ap & M-A \\
\hline 180 & Veronica chamaedrys & Scrophulariaceae & $\mathrm{C}$ & Ap & - \\
\hline 181 & Veronica longifolia & Scrophulariaceae & $\mathrm{H}$ & $\mathrm{Sn}$ & M-A \\
\hline 182 & Viburnum opulus & Caprifoliaceae & $\mathrm{N}$ & Ap & R-P \\
\hline 183 & Vicia cracca & Fabaceae & $\mathrm{H}$ & Ap & M-A \\
\hline 184 & Vicia tenuifolia & Fabaceae & $\mathrm{HG}$ & $\mathrm{Sn}$ & $\mathrm{T}-\mathrm{G}$ \\
\hline 185 & Viola arvensis & Violaceae & $\mathrm{T}$ & $\mathrm{Ar}$ & SM \\
\hline 186 & Viola odorata & Violaceae & $\mathrm{H}$ & Ap & Q-F \\
\hline
\end{tabular}

GRRA - life forms of Raunkiaer; GRHG - geographic-historical group of species; $\mathrm{ChCl}$ - characteristic species of the class: AG - Alnetea glutinosae, AI-R - Agropyretea intermedio-repentis, AT - Asteretea tripolium, AV - Artemisietea vulgaris, B-A - Betulo-Adenostyletea, BT - Bidentetea tripartiti, EA - Epilobietea angustifolii, F-B - Festuco-Brometea, K-C - Koelerio glaucae-Corynephoretea canescentis, M-A - Molinio-Arrhenatheretea, N-C - Nardo-Callunetea, P - Phragmitetea, Q-F - Querco-Fagetea, R-P - Rhamno-Prunetea, S-CN - Scheuchzerio-Caricetea nigrae, SM - Stellarietea mediae, SP - Salicetea purpureae, T-G - Trifolio-Geranietea sanguinei, V-P - Vaccinio-Piceetea, "-" - accompaning species. 